\title{
Beyond the protein concept: health aspects of using edible insects on animals
}

\author{
L. $\operatorname{Gasco}^{1^{*}}$, A. Józefiak ${ }^{2}$ and M. Henry ${ }^{3}$ \\ ${ }^{1}$ Department of Agricultural, Forest and Food Sciences, University of Torino, Largo P. Braccini 2, 10095 Grugliasco, Italy; \\ ${ }^{2}$ Department of Preclinical Sciences and Infectious Diseases, Poznan University of Life Sciences, Wotyńska 35, 60-637 \\ Poznań, Poland; ${ }^{3}$ Institute of Marine Biology, Biotechnology and Aquaculture, Hellenic Centre for Marine Research, 46.7 \\ Athinon - Souniouave, 19013 Anavissos, Attiki, Greece; laura.gasco@unito.it
}

Received: 10 July 2020 / Accepted: 30 September 2020

(c) 2020 Wageningen Academic Publishers

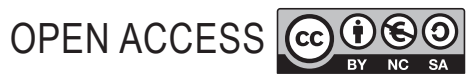

REVIEW ARTICLE

\begin{abstract}
There is an increasing interest in the use of insects in animal feed since they contain high proteins levels, lipids, vitamins and minerals. In particular, insect-derived proteins are seen as one of the potential solution to face the increasing protein shortage and are able to fully substitute soybean meal or fishmeal in aquaculture or livestock feeds. However, beside their interesting nutritional composition, insects are also rich in bioactive compounds such as chitin, antimicrobial peptides or specific fatty acids with immunostimulating, antimicrobial and/or antiinflammatory properties able to sustain animal health, increase their resistance to diseases. Further studies will also have to investigate whether insects share similarities with bacterial or parasitical pathogens and may act as immunostimulants. These recent findings may launch insects beyond the protein concept into healthy animal feeds. This review presents the effects of insects and their bioactive compounds on fish and crustaceans, poultry, pigs and rabbits immune system, gut health, microbiota and resistance to diseases.
\end{abstract}

Keywords: gut health, microbiota, antioxidant enzymes, immunity, disease resistance

\section{Introduction}

Since the dawn of time, insects have been part of our life, being considered as a pest, a resource, food and, more recently, as a feed for intensive livestock production. Pest insects are known to have detrimental impacts on agricultural and food production as they damage crops and parasitise livestock (Bradshaw et al., 2016; FAO, 2020; Paini et al., 2016), and they can also be a great nuisance and health hazard for human (WHO, 2015).

Nevertheless, apart from being considered a great nuisance, insects are responsible for the production of about one third of our food through the pollination process and, as such, they are a great asset playing a key role in all terrestrial and freshwater ecosystems. If all insects were to disappear, human food supply would run out in about four years (Goulson, 2019; Noriega et al., 2018).

Insects were already a major food source 1.2 million years ago (Hardy et al., 2016; Van Huis, 2017) and they are still today part of the modern diet of more than two billion people, in particular in non-Western countries (Kouřimská and Adámková, 2016; van Huis, 2020).

The interest in insects has recently turned to their use in animal nutrition. Insect have a high nutritional value and species that undergo a non-feeding phase (pupae), store energy as fat and thus contain large quantities of triacylglycerol which are recalled in periods of high-energy demand. The fatty acid (FA) profile of insects is speciesspecific and related to the sex, life stage and environmental conditions of the insects (Oonincx et al. 2015), and most interestingly, it can be modulated by the rearing substrate to ameliorate the FA profile of the fed animals (Danieli et al., 2019; Liland et al., 2017; St Hilaire et al., 2007). A fraction of this fat is usually extracted during the insect meal production process, and the resulting defatted raw material is a powder which vary in protein content and can exceed $70 \%$ (on a dry matter (DM) basis) (Figure 1). (Gasco et al., 2020a; Józefiak et al., 2016). As a result of their high nutritional value, and in particular their high 


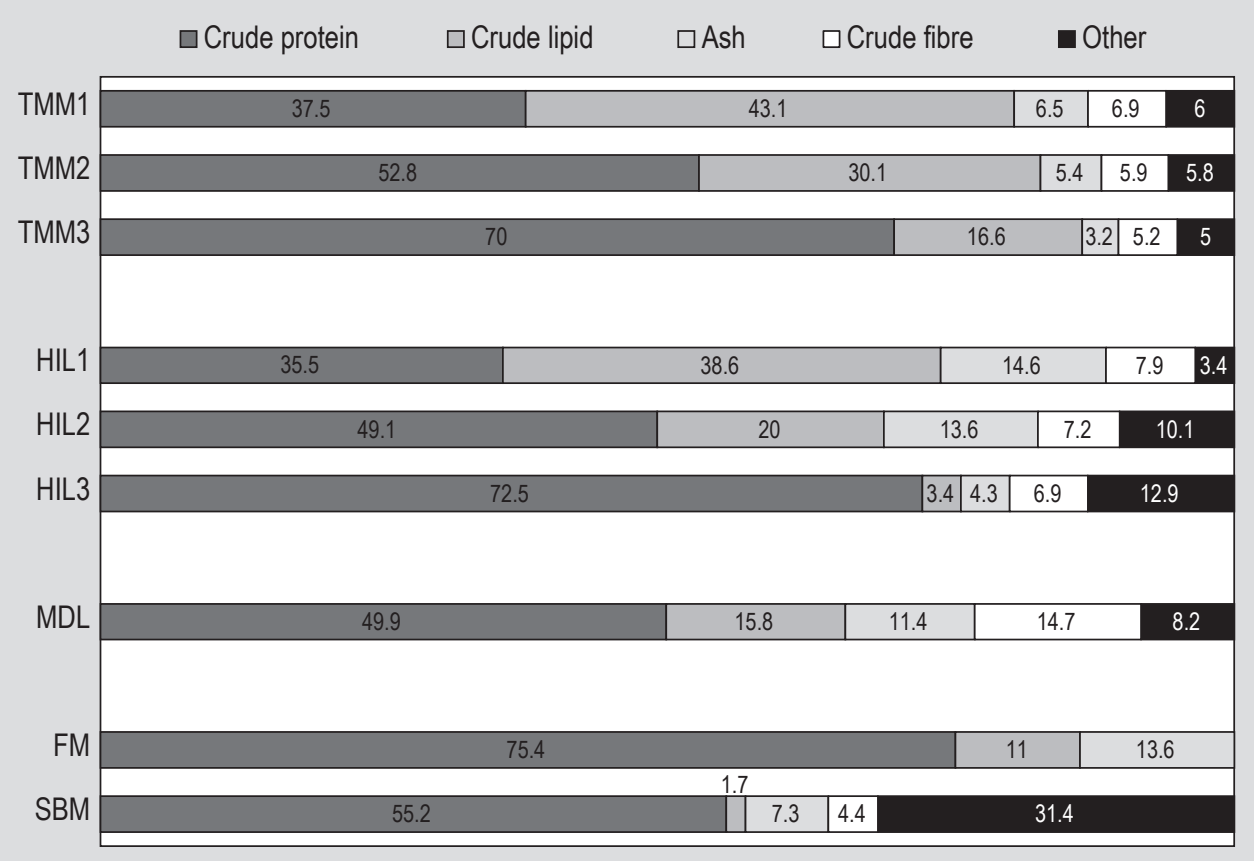

Figure 1. Nutrient composition of Tenebrio molitor, Hermetia illucens and Musca domestica larvae meals compared to fishmeal and soybean meal (\% of dry matter) (elaborated from Gasco et al., 2018a). FM = fishmeal; HIL1, HIL2, HIL3 = Hermetia illucens larvae meals obtained under different production process; MDL = Musca domestica larvae meal; SBM = soybean meal; TMM1, TMM2, TMM3 = Tenebrio molitor larvae meals obtained under different production process.

protein content, they represent excellent alternatives to conventional protein sources, such as soybean meal (SBM) or fishmeal (FM) in animal feed (De Souza et al., 2019; Gasco et al., 2018a, 2019a, 2020a,b; Henry et al., 2015; Józefiak and Engberg 2017; Khan, 2018; Koutsos et al., 2019; Lock et al., 2018; Nogales-Mérida et al. 2019; Sogari et al., 2019). Moreover, many insect species bio-convert organic substrates into valuable protein- and energy-rich products thus contributing to the Circular Economy principle (Gasco et al., 2020b). In fact, the use of otherwise non-utilised sidestreams as substrates for insects enables the production of high-value products with low environmental impacts (Bosch et al., 2019; Smetana et al., 2019).

So far, only a few insect species are being mass reared for feed purposes, the most studied being the black soldier fly (Hermetia illucens; HI), the common housefly (Musca domestica; MD), and the yellow mealworm (Tenebrio molitor; TM). They have a valuable amino acid profile similar to those of SBM and FM partially or totally covering the requirements of fish and livestock species (Figure 2).

Although, at the beginning, insects were mainly appreciated for their protein and energy supply, their newly discovered bioactive compounds may promote animal health and launch insects beyond the 'simple' protein concept (Gasco et al., 2018b; Józefiak and Engberg 2017; Lee et al., 2018; Wu et al., 2018). This review presents the main effects of insects and their bioactive compounds on fish and crustaceans, poultry, pigs and rabbits.

Preparing this article, an accurate bibliographical search was performed to collect all relevant references on the effects of dietary insects on animal health. The interest on this subject is recent and the search returned increasing numbers of references from 2011 to 2020. In addition to personal databases of articles collected since 2011 by the 3 authors and shared between them, academic articles were sourced from Google, Web of Science, Scopus and Science direct. Different key words were used, alone or in association with each others, such as 'insects', 'edible insects', 'insect feed,' 'poultry', 'fish', 'teleost,' 'pigs', 'piglets', 'rabbit', 'health effect', 'gut health', 'microbiota' 'immunology,' 'antimicrobial peptides'. The search terms also consisted of the insect common names in English (e.g. 'yellow mealworm, 'black soldier fly', 'lesser meal worm' or 'common housefly') or the Latin names (e.g. 'Tenebrio molitor', 'Hermetia illucens', 'Zophobas morio' or 'Musca domestica'). The full text of each article was downloaded, read and when pertinent, used for the current review. All newly found articles were added to the common database. In all, about 950 articles were found of which 130 on fish, 113 on poultry, 36 on pigs, 7 on crustaceans, 4 on rabbits and more than 93 concerning antimicrobial peptides, chitin or microbiome. 


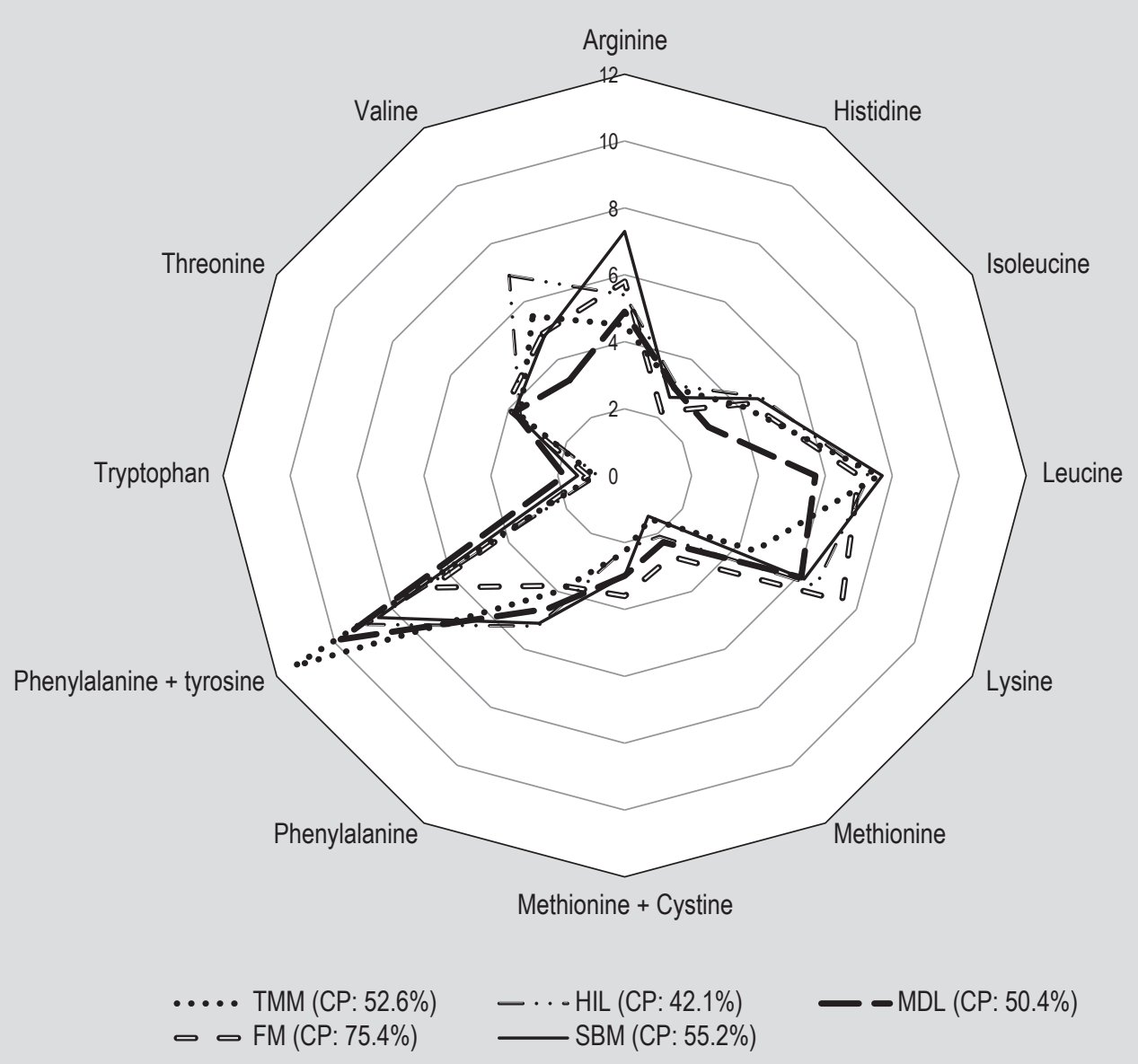

Figure 2. Main amino acid composition of Tenebrio molitor, Hermetia illucens and Musca domestica larvae meals compared to fishmeal and soybean meal (\% of protein dry matter) (Gasco et al., 2018a and Feedipedia.org). FM = fishmeal; HIL = Hermetia illucens larvae meal; $\mathrm{MDL}$ = Musca domestica larvae meal; SBM = soybean meal; TMM = Tenebrio molitor larvae meal.

Considering insect products and their effects on animal health, only peer-reviewed articles written in English language and published during the last decade were considered for further evaluation to ensure contemporary scientific quality and timeliness of the review. At the end, without considering more general articles used in the introduction part, a total of 129 articles were included in this review.

\section{Microbiota modulation and gut health}

The importance of gut health in general health has recently been underlined for both mammals and other animals. Until recently, gut health was mainly assessed through histological observations. The development of 16S RNA based on high throughput sequencing techniques has enabled the precise detection of complex microbial communities in animals gastrointestinal tract (GIT), named microbiota, which has been closely linked not only to digestion but also to immunity and resistance of the animals to diseases (Egerton et al., 2018; Kayama et al., 2020; McCarville et al., 2020). Diet composition is recognised as one of the major factors affecting this gut microbiota and dietary insects may subsequently modulate the gut microbiota of the animals feeding on these insects (Vogel et al., 2018).

\section{Fish and crustaceans}

Crustaceans and fish gut health and microbiota are influenced by dietary insects (HI, listed in Table 1; TM, listed in Table 2; and other insects listed in Table 3).

\section{Fish and crustaceans gut morphology and physiology}

Insect meal did not generally show any adverse effect on the gut morphology of fish (Caimi et al., 2020; Elia et al., 2018; Lock et al., 2016; Wang et al., 2019) or on their gut digestive enzymes (Belghit et al., 2019; Li et al., 2017a; Wang et al., 2019). Some exceptions concerned dietary HI (Table 1) found to induce some villus irregularities in Jian carp (Li et al., 2017a), villus shortening in clown fish (Vargas-Abundez et al., 2019) and rainbow trout (Cardinaletti et al., 2019), increased gut lipase activity in Japanese sea bass (Wang et al., 2019) but decreased in European sea bass (Magalhaes 
Table 1. Effects of Hermetia illucens products on gut health and microbiota in fish and crustacean. ${ }^{1}$

\begin{tabular}{|c|c|c|c|c|c|c|c|c|}
\hline \multirow[t]{2}{*}{$\begin{array}{l}\text { Animal } \\
\text { [IBW-FBW, g] } \\
\text { \{no. days }\end{array}$} & \multirow[t]{2}{*}{$\begin{array}{l}\text { Insect } \\
\text { [form] }\end{array}$} & \multicolumn{2}{|c|}{ 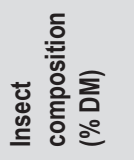 } & \multirow{2}{*}{ 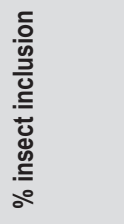 } & \multirow{2}{*}{ 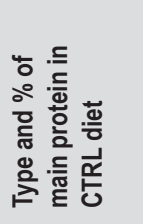 } & \multirow{2}{*}{ 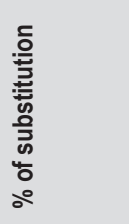 } & \multirow[t]{2}{*}{ Gut health and microbiota } & \multirow[t]{2}{*}{ Reference } \\
\hline & & $\mathrm{CP}$ & $\mathrm{CL}$ & & & & & \\
\hline $\begin{array}{l}\text { Marron (Cherax } \\
\text { cainii) } \\
{[65-89]\{60\}}\end{array}$ & HIL & - & - & 12,11 & $\begin{array}{l}\text { FM: } 41 \% \text { or } \\
\text { PBP: } 39 \%\end{array}$ & 22,19 & $\begin{array}{l}\text { Increased richness and diversity of microbiota; } \\
\text { Bacterioidetes, Proteobacteria and Firmicutes } \\
\text { LAB; decrease of Vibrio and Enterobacter }\end{array}$ & $\begin{array}{l}\text { Foysal et al. } \\
(2019)\end{array}$ \\
\hline $\begin{array}{l}\text { Zebrafish (Danio } \\
\text { rerio) } \\
{[2-21 \mathrm{dps}]\{19\}}\end{array}$ & HIP [FF] & & & $10.5,21$ & FM: $42 \%$ & 25,50 & $\begin{array}{l}\text { No intestinal inflammation; lipid accumulation } \\
\text { in liver of fish fed } 21 \% \text { HIL; higher chitinase } \\
\text { expression at } 21 \% \mathrm{HI}\end{array}$ & $\begin{array}{l}\text { Zarantoniello et } \\
\text { al. (2018) }\end{array}$ \\
\hline $\begin{array}{l}\text { Jian carp (Cyprinus } \\
\text { carpio var. Jian) } \\
{[35-110]\{59\}}\end{array}$ & HIL [DF] & - & - & $\begin{array}{l}2.6,5.3 \\
7.9,10.6\end{array}$ & FM: $10 \%$ & $\begin{array}{l}25,50,75 \\
100\end{array}$ & $\begin{array}{l}\text { At HIL }>75 \% \text {, irregularities of gut microvilli shape, } \\
\text { no effect on gut digestive enzymes }\end{array}$ & Li et al. $(2017 a, b)$ \\
\hline $\begin{array}{l}\text { Siberian sturgeon } \\
\text { (Acipenser baerii) } \\
{[24-159]\{118\}}\end{array}$ & HIL [DF] & 65.8 & 4.24 & $18.5,37.5$ & FM: $70 \%$ & 25,50 & No effect on histology of liver or gut & $\begin{array}{l}\text { Caimi et al. } \\
(2020)\end{array}$ \\
\hline $\begin{array}{l}\text { Siberian sturgeon } \\
\text { (A. baerii) } \\
{[640-1,200]\{60\}}\end{array}$ & HIL [FF] & 40.4 & 33.5 & 15 & FM: $26 \%$ & 30 & $\begin{array}{l}\text { Reduced thickness of mucosa, no difference of villi } \\
\text { height; increased richness of microbiota, increased } \\
\text { numbers of Clostridium, Enterobacteriaceae, } \\
\text { Aeromonas, Bacillus, Carnobacterium, } \\
\text { Enterococcus, Lactobacillus }\end{array}$ & $\begin{array}{l}\text { Józefiak et al. } \\
\text { (2019a) }\end{array}$ \\
\hline $\begin{array}{l}\text { Rainbow trout, } \\
\text { (Oncorhynchus } \\
\text { mykiss) } \\
{[53-166]\{71\}}\end{array}$ & HIP [FF] & 56.3 & 23.5 & 20 & FM: $34.8 \%$ & 30 & $\begin{array}{l}\text { Slight decrease of villi height in the proximal } \\
\text { intestine; no change of mucosal thickness; } \\
\text { increased richness of microbiota; increased } \\
\text { Clostridium and LAB }\end{array}$ & $\begin{array}{l}\text { Józefiak et al. } \\
\text { (2019b) }\end{array}$ \\
\hline $\begin{array}{l}\text { Rainbow trout }(0 . \\
\text { mykiss) } \\
{[66-223]\{84\}}\end{array}$ & HIL [DF] & 48.6 & 20.6 & $10,20,30$ & FM: $60 \%$ & $10,20,30$ & $\begin{array}{l}\text { Increased richness and diversity of } \\
\text { microbiota in faecal samples, increased } \\
\text { lactic acid and butyrate-producing bacteria; } \\
\text { Actinomycetaceae, Bacillaceae, Lactobacillaceae, } \\
\text { Staphylococcaceae, reduced Vibrionacae, } \\
\text { Pseudomonaceae and Enterobacteriaceae; } \\
\text { Firmicutes rich in faeces of HIL-fed trout, } \\
\text { not in gut mucosa. Gut mucosa (adhered } \\
\text { intestinal microbiota) of HIL-fed fish showed } \\
\text { increased diversity but not richness; reduction } \\
\text { of Proteobacteria, increased abundance of } \\
\text { Mycoplasma in gut mucosa. }\end{array}$ & $\begin{array}{l}\text { Terova et al. } \\
\text { (2019) (gut } \\
\text { content); Rimoldi } \\
\text { et al. (2019) (gut } \\
\text { mucosa) }\end{array}$ \\
\hline $\begin{array}{l}\text { Rainbow trout }(0 . \\
\text { mykiss) } \\
{[137-300]\{98\}}\end{array}$ & HIP [FF] & 39.0 & 41.9 & $10.5,21$ & FM: $42 \%$ & 25,50 & $\begin{array}{l}\text { Increased golblet cells (hyperplasia) producing } \\
\text { neutral mucins in hind intestine; shortening of mid } \\
\text { intestine villi; no intestinal inflammation; increased } \\
\text { lipid accumulation in liver at } 21 \% \text { HIP }\end{array}$ & $\begin{array}{l}\text { Cardinaletti et al. } \\
\text { (2019) }\end{array}$ \\
\hline $\begin{array}{l}\text { Rainbow trout }(0 . \\
\text { mykiss }) \\
{[179-540]\{78\}}\end{array}$ & HIL [FF] & 55.3 & 18 & 20,40 & FM: $60 \%$ & 25,50 & $\begin{array}{l}\text { No change of gut morphology; no effect on } \\
\text { histology of liver, spleen or gut, acidic and neutral } \\
\text { mucin; increased diversity of microbiota especially } \\
\text { at } 20 \% \text {, Proteobacter and Tenericutes most } \\
\text { abundant in HIL-fed trout }\end{array}$ & $\begin{array}{l}\text { Elia et al. (2018); } \\
\text { Bruni et al. } \\
(2018)\end{array}$ \\
\hline
\end{tabular}


Table 1. Continued.

\begin{tabular}{|c|c|c|c|c|c|c|c|c|}
\hline \multirow[t]{2}{*}{$\begin{array}{l}\text { Animal } \\
\text { [IBW-FBW, g] } \\
\text { \{no. days }\end{array}$} & \multirow[t]{2}{*}{$\begin{array}{l}\text { Insect } \\
\text { [form] }\end{array}$} & \multicolumn{2}{|c|}{ 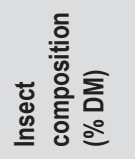 } & \multirow{2}{*}{ 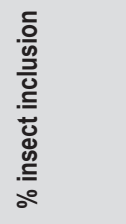 } & \multirow{2}{*}{ 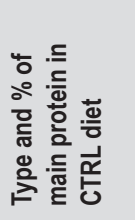 } & \multirow{2}{*}{ 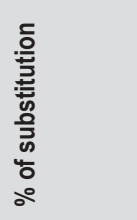 } & \multirow[t]{2}{*}{ Gut health and microbiota } & \multirow[t]{2}{*}{ Reference } \\
\hline & & $\mathrm{CP}$ & $\mathrm{CL}$ & & & & & \\
\hline \multirow{3}{*}{$\begin{array}{l}\text { Rainbow trout } \\
\text { (O. mykiss) } \\
{[202-276]\{35\}}\end{array}$} & HIP [FF] & - & - & 30 & FM: $50 \%$ & 30 & $\begin{array}{l}\text { Best diversity and richness of microbiota; rich in } \\
\text { Actinobacteria }\end{array}$ & $\begin{array}{l}\text { Huyben et al. } \\
(2019)\end{array}$ \\
\hline & HIL [FF] & - & - & & & & $\begin{array}{l}\text { Intermediate diversity and lowest richness of } \\
\text { microbiota between } 3 \text { HIL but still richer than FM- } \\
\text { fed fish; high firmicutes; high LAB }\end{array}$ & \\
\hline & HIL [DF] & - & - & & & & $\begin{array}{l}\text { Lowest diversity and intermediate richness } \\
\text { of microbiota still better than FM; very high } \\
\text { Firmicutes (Bacillaceae) }\end{array}$ & \\
\hline $\begin{array}{l}\text { Atlantic salmon } \\
\text { (Salmo salar) } \\
{[49-143]\{56\}}\end{array}$ & HIL [DF] & & - & 60 & $\begin{array}{l}\text { FM: } 35 \% \\
+ \text { SPC: } \\
29.6 \%\end{array}$ & 85 & $\begin{array}{l}\text { Decreased hyper-vacuolisation of proximal } \\
\text { intestinal enterocytes; normal histological structure } \\
\text { of mid- and distal intestine but of increased weight } \\
\text { compared to ctrl fish, maybe related to increased } \\
\text { butyrate }\end{array}$ & $\begin{array}{l}\text { Li et al. (2019); } \\
\text { Belghit et al. } \\
(2018)\end{array}$ \\
\hline $\begin{array}{l}\text { Atlantic salmon } \\
\text { (S. salar) } \\
\text { [247-from } 359 \text { to }\end{array}$ & HIL [FF] & 54.1 & 26.4 & $5,10,25$ & FM: $20 \%$ & $25,50,100$ & No effect on gut histology & Lock et al. (2016) \\
\hline 575$]\{105\}$ & & 61.0 & 17.8 & 5,25 & & 25,100 & & \\
\hline $\begin{array}{l}\text { Atlantic salmon } \\
\text { (S. salar) } \\
{[1,400-3,702]\{112\}}\end{array}$ & HIL [DF] & 52 & 18 & $5,10,15$ & FM: $10 \%$ & $33,66,100$ & $\begin{array}{l}\text { At } 15 \% \text { HIL, lower enterocytes steatosis in } \\
\text { proximal intestine, increased distal intestine } \\
\text { weight. At } 5,10 \text { and } 15 \% \text { HIL, no effect on } \\
\text { digestive brush border enzymes or total bile acids } \\
\text { in the digesta }\end{array}$ & $\begin{array}{l}\text { Belghit et al. } \\
\text { (2019); Li et al. } \\
(2020)\end{array}$ \\
\hline $\begin{array}{l}\text { European sea bass } \\
\text { (Dicentrarchus } \\
\text { labrax) } \\
{[50-129]\{62\}}\end{array}$ & HIP [DF] & 55.8 & 5.5 & $\begin{array}{l}6.5,13 \\
19.5\end{array}$ & FM: $32.4 \%$ & $15,30,45$ & $\begin{array}{l}\text { No effect on gut digestive enzymes except for } \\
\text { lipase lower at } 6.5 \text { compared to FM ctrl and } 19.5 \% \\
\text { HIP in both anterior and posterior intestine }\end{array}$ & $\begin{array}{l}\text { Magalhaes et al. } \\
\text { (2017) }\end{array}$ \\
\hline $\begin{array}{l}\text { Clownfish } \\
\text { (Amphiprion } \\
\text { ocellaris) } \\
\text { [juveniles]\{106\} }\end{array}$ & HIL [DF] & - & - & $20,40,60$ & FM: $60 \%$ & $25,50,75$ & $\begin{array}{l}\text { No intestinal inflammation, reduced villi at } \\
\text { HIL }>40 \%\end{array}$ & $\begin{array}{l}\text { Vargas-Abundez } \\
\text { et al. (2019) }\end{array}$ \\
\hline
\end{tabular}

et al., 2017), increased weight of the distal intestine of Atlantic salmon (Li et al., 2019, 2020) and reduced steatosis (i.e. abnormal fat retention) of the proximal intestine in Atlantic salmon (Li et al., 2020). The dietary inclusion of $\mathrm{HI}$ also increased submuscosa cellularity and production of neutral mucin by the goblet cells in the proximal intestine of rainbow trout (Cardinaletti et al., 2019; Elia et al., 2018). Mucosal and muscular layer thickening of the GIT was also shown in sturgeon fed TM (Józefiak et al., 2019a; Table 1 and 2). This may be related to the production of short-chain fatty acids (SCFA; such as butyrate), which are metabolites of the microbiota known to stimulate the proliferation of mucosal cells in the colon of humans (Mortensen et al., 1999). Microbiota studies on crustaceans and fish have been performed on rainbow trout and few other freshwater and marine fish species fed mainly on HI (Table 1) and TM (Table 2), but recent studies have also investigated the effects of MD, Gryllus sigillatus, Blatta lateralis and Zophoba morio (ZM) (Table 3). 
Table 2. Effects of Tenebrio molitor products on gut health and microbiota in fish and crustacean. ${ }^{1}$

\begin{tabular}{|c|c|c|c|c|c|c|c|c|}
\hline \multirow[t]{2}{*}{$\begin{array}{l}\text { Animal } \\
\text { [IBW-FBW, g] } \\
\text { \{no. days }\end{array}$} & \multirow[t]{2}{*}{$\begin{array}{l}\text { Insect } \\
\text { [form] }\end{array}$} & \multicolumn{2}{|c|}{ 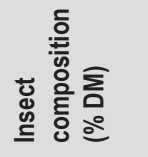 } & \multirow{2}{*}{ 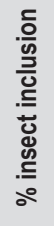 } & \multirow{2}{*}{ 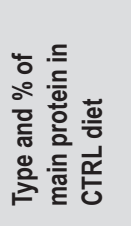 } & \multirow{2}{*}{ 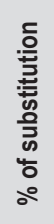 } & \multirow[t]{2}{*}{ Gut health and microbiota } & \multirow[t]{2}{*}{ Reference } \\
\hline & & $\mathrm{CP}$ & $\mathrm{CL}$ & & & & & \\
\hline $\begin{array}{l}\text { Siberian sturgeon } \\
\text { (Acipenser baerii) } \\
{[640-1,200]\{60\}}\end{array}$ & TMM [FF] & 56.3 & 25.3 & 15 & FM: $26 \%$ & 40 & $\begin{array}{l}\text { Increased thickness of muscular layer, no difference } \\
\text { of villi height; reduced richness of microbiota; no } \\
\text { effect on intestinal Clostridium, Enterobacteriaceae, } \\
\text { Lactobacillus or Enterococcus. Increased Bacillus, } \\
\text { Carnobacterium and Enterococcus }\end{array}$ & $\begin{array}{l}\text { Józefiak et al. } \\
\text { (2019a) }\end{array}$ \\
\hline $\begin{array}{l}\text { Rainbow trout } \\
\text { (Oncorhynchus } \\
\text { mykiss) } \\
{[53-166]\{71\}}\end{array}$ & TMM [FF] & 56.3 & 25.3 & 20 & FM: $34.8 \%$ & 40 & $\begin{array}{l}\text { Decrease of villi height in the proximal intestine; no } \\
\text { change of mucosal thickness; strongly increased } \\
\text { richness of microbiota; strongly increased Clostridium; } \\
\text { Enterobacteriaceae and LAB }\end{array}$ & $\begin{array}{l}\text { Józefiak et al. } \\
\text { (2019b) }\end{array}$ \\
\hline $\begin{array}{l}\text { Rainbow trout }(0 . \\
\text { mykiss) } \\
\text { [115-no data] }\{90\}\end{array}$ & TMM [FF] & 51.9 & 23.6 & 60 & FM: $70 \%$ & 86 & Decreased diversity of microbiota & $\begin{array}{l}\text { Antonopoulou et } \\
\text { al. (2019) }\end{array}$ \\
\hline $\begin{array}{l}\text { Sea trout (Salmo trutta } \\
\text { m. trutta) } \\
{[5-21]\{56\}}\end{array}$ & $\begin{array}{l}\text { TMM } \\
\text { [hydrolysed] }\end{array}$ & 47 & 29.6 & 10 & FM: $25 \%$ & 58 & $\begin{array}{l}\text { Slight increase of villi height; no change in muscular } \\
\text { layer thickness of the anterior intestine; no change in } \\
\text { microbiota richness; reduction of Carnobacterium and } \\
\text { Lactobacillus }\end{array}$ & $\begin{array}{l}\text { Mikolajczak et al } \\
(2020)\end{array}$ \\
\hline $\begin{array}{l}\text { European sea bass } \\
\text { (Dicentrarchus labrax) } \\
\text { [5-from } 17 \text { to 22] }\{70\}\end{array}$ & TMM [FF] & 51.9 & 23.6 & 50 & FM: $70 \%$ & 71 & $\begin{array}{l}\text { Increased diversity of microbiota, increased abundance } \\
\text { of Tenericutes }\end{array}$ & $\begin{array}{l}\text { Antonopoulou et } \\
\text { al. (2019) }\end{array}$ \\
\hline $\begin{array}{l}\text { Gilthead seabream } \\
\text { (Sparus aurata) } \\
{[105-240]\{163\}}\end{array}$ & TMM [FF] & 51.9 & 23.6 & 50 & FM: $50 \%$ & 74 & $\begin{array}{l}\text { increased diversity of microbiota, increased abundance } \\
\text { of Tenericutes }\end{array}$ & $\begin{array}{l}\text { Antonopoulou et } \\
\text { al. (2019) }\end{array}$ \\
\hline
\end{tabular}

\section{Fish and crustaceans gut microbiota}

The microbiota of fish is closely correlated to the host diet and dietary insects have been suggested to act as prebiotics through both an improvement of the gut absorptive area and the stimulation of the host immunity to fight pathogenic bacteria, thus favouring beneficial commensal bacteria (Guerrerio et al., 2018; Józefiak et al., 2019a). In crustaceans, a dietary supplementation of $\mathrm{HI}$ increased the richness and diversity of the gut microbiota of marron (Cherax cainii) (Foysal et al., 2019). The opposite was true in swamp eel where the replacement of a control diet with whole MD larva every 3 or 7 days reduced the gut microbiota richness and diversity. However, the fish did not grow well in this unique study showing adverse effect of dietary insects on fish microbiota (Xiang et al., 2019). Indeed, although dietary TM or ZM did not affect the richness of sea trout's microbiota, they significantly reduced the occurrence of potential pathogens (Mikołajczak et al., 2020). Moreover, several studies have shown that both HI and TM increased the gut microbiota diversity of rainbow trout (Antonopoulou et al., 2019; Huyben et al., 2019; Józefiak et al., 2019b). Dietary crustacean chitin and chitosan have been shown to enrich and diversify fish microbiota (Askarian et al., 2012; Ringø et al., 2012; Udayangani et al., 2017), acting as prebiotics and contributing to a healthy gut, decreasing the abundance of fish pathogenic bacteria and thus increasing disease resistance (Qin et al., 2014; Terova et al., 2019; Zhou et al., 2013). Insect chitin may have a similar prebiotic effect (Huyben et al., 2019), although this has not been demonstrated as yet. Nevertheless, dietary insects have been shown to cause a shift of microbiota of crustaceans and fish towards an increased importance of Tenericutes, Actinomycetes, Clostridiales and/or Firmicutes suggested to be chitinolytic bacteria facilitating the digestion of chitin-rich nutrients (Elia et al., 2018; Bruni et al., 2018; Antonopoulou et al., 2019; Foysal et al., 2019; Huyben et al., 2019; Józefiak et al., 2019b; Terova et al., 2019). In particular, Firmicutes lactic acid producing bacteria (LAB), often used as probiotics 
Table 3. Effects of Musca domestica, Chironomidae, Gryllus sigillatus, Blatta lateralis and Zophoba morio on gut health and microbiota in fish and crustacean. ${ }^{1}$

\begin{tabular}{|c|c|c|c|c|c|c|c|c|}
\hline \multirow[t]{2}{*}{$\begin{array}{l}\text { Animal } \\
\text { [IBW-FBW, g] } \\
\text { \{no. days }\end{array}$} & \multirow[t]{2}{*}{$\begin{array}{l}\text { Insect } \\
\text { [form] }\end{array}$} & \multicolumn{2}{|c|}{ 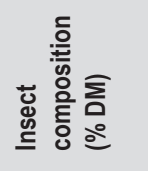 } & \multirow{2}{*}{ 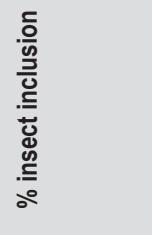 } & \multirow{2}{*}{ 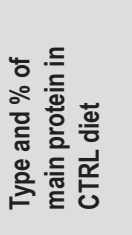 } & \multirow{2}{*}{ 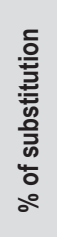 } & \multirow[t]{2}{*}{ Gut health and microbiota } & \multirow[t]{2}{*}{ Reference } \\
\hline & & $\mathrm{CP}$ & CL & & & & & \\
\hline $\begin{array}{l}\text { Swamp eel } \\
\text { (Monopterus albus) } \\
{[27-31]\{56\}}\end{array}$ & MDL [whole] & 64 & 24.3 & $\begin{array}{l}1 \text { day every } \\
3(1 \mathrm{~d} / 3) \text { or } 7 \\
\text { days }(1 \mathrm{~d} / 7)\end{array}$ & FM: $45 \%$ & & $\begin{array}{l}\text { At } 1 \mathrm{~d} / 7 \text {, poorer microbiota and less diverse, } \\
\text { decreased Pseudomonas. At } 1 \mathrm{~d} / 3 \text {, more } \\
\text { Bacterioidaceae, decreased Pseudomonas }\end{array}$ & $\begin{array}{l}\text { Xiang et al. } \\
(2019)\end{array}$ \\
\hline $\begin{array}{l}\text { Rainbow trout } \\
\text { (Oncorhynchus } \\
\text { mykiss) } \\
{[0.13-0.65]\{28\}}\end{array}$ & $\begin{array}{l}\text { ChL [whole } \\
\text { frozen] }\end{array}$ & 66 & 9 & 100 & FM: $12.4 \%$ & & $\begin{array}{l}\text { Distal intestine more folded, with higher brush } \\
\text { border, less goblet cells }\end{array}$ & $\begin{array}{l}\text { Ostaszewska et } \\
\text { al. (2011) }\end{array}$ \\
\hline $\begin{array}{l}\text { Rainbow trout trout } \\
\text { (O. mykiss) } \\
{[53-166]\{71\}}\end{array}$ & GSA [FF] & 61.3 & 19.5 & 20 & FM: $34.8 \%$ & 48 & $\begin{array}{l}\text { Decrease of villi height in the proximal intestine; } \\
\text { decrease of mucosal thickness; increased } \\
\text { richness of microbiota; increased Clostridium and } \\
\text { LAB }\end{array}$ & $\begin{array}{l}\text { Józefiak et al. } \\
\text { (2019b) }\end{array}$ \\
\hline $\begin{array}{l}\text { Rainbow trout trout } \\
\text { (0. mykiss) } \\
{[53-166]\{71\}}\end{array}$ & $\mathrm{BLA}[\mathrm{FF}]$ & 54.6 & 26.1 & 20 & FM: $34.8 \%$ & 42 & $\begin{array}{l}\text { Decreased growth; Increase of villi height in the } \\
\text { proximal intestine; increase of mucosal thickness; } \\
\text { increased richness of microbiota; increased } \\
\text { Clostridium and LAB }\end{array}$ & $\begin{array}{l}\text { Józefiak et al. } \\
\text { (2019b) }\end{array}$ \\
\hline $\begin{array}{l}\text { Sea trout (Salmo } \\
\text { trutta m. trutta) } \\
{[5-21]\{56\}}\end{array}$ & $\begin{array}{l}\text { ZMM } \\
\text { [hydrolysed] }\end{array}$ & 49.3 & 33.6 & 10 & FM: $25 \%$ & 56 & $\begin{array}{l}\text { No change in villi height or muscular layer } \\
\text { thickness of the anterior intestine; no change in } \\
\text { richness of microbiota; reduction of Aeromonas, } \\
\text { Carnobacterium and Enterococcus }\end{array}$ & $\begin{array}{l}\text { Mikolajczak et al. } \\
\text { (2020) }\end{array}$ \\
\hline
\end{tabular}

${ }^{1} \mathrm{BLA}=$ Blatta lateralis adults; $\mathrm{ChL}=$ Chironomidae larvae; $\mathrm{CL}=$ crude lipid $\mathrm{CP}=$ crude protein; $\mathrm{CTRL}=$ control diet; dps = days post-spawning; $\mathrm{DM}=$ dry matter; FBW = final body weight; $F F=$ full fat; FM = fishmeal; $G S A=$ Gryllus sigillatus adults; $I B W=$ initial body weight; $L A B=$ lactic-acid producing bacteria; $M D L=$ Musca domestica larvae meal; ZMM = Zophoba morio larval meal.

and known to improve mucosal activity and to produce antimicrobial bacteriocins, were more abundant in the intestines of rainbow trout and Siberian sturgeon fed with HI (Bruni et al., 2018; Huyben et al., 2019; Józefiak et al., 2019a,b, Terova et al., 2019). However, this was not the case of sea trout fed TM, where Lactobacillus counts reduced compared to FM-fed fish (Mikołajczak et al., 2020). Other commensal bacteria with antibacterial or antiviral activity (e.g. Pseudomonas stutzeri, Carnobacterium divergens, Acinetobacter spp.) and with the potential to help the host fight or compete with pathogens were observed to be particularly abundant in HI-fed rainbow trout (Bruni et al., 2018). Moreover, bacterial genera associated with common fish or human pathogens (Pseudomonas, Vibrio, Aeromonas and Enterococcus) decreased in HI-fed rainbow trout (Rimoldi et al., 2019; Terova et al., 2019), TM- and ZM-fed sea trout (Mikołajczak et al., 2020) as well as in MDfed swamp eel (Xiang et al., 2019). Insect meals are usually rich in saturated SCFA such as lauric acid, propionate and butyrate, which are antibacterial and antiviral, and may thus be responsible for some of the modulating activity of dietary insects on the gut microbiota of fish described above
(Terova et al., 2019). In turn, dietary insects were shown to favour commensal bacteria of the Clostridiales order, which also produce SCFA reinforcing their contribution to the gut microbiomic homeostasis of fish (Józefiak et al., 2019 a,b; Terova et al., 2019). Moreover, SCFA are also known to be anti-inflammatory (Vargas-Abundez et al., 2019) and may be involved in the absence of gut inflammation observed in insect meal-fed fish (Cardinaletti et al., 2019; Li et al., 2019; Zaratoniello et al., 2018).

\section{Poultry}

In nature, most birds are primarily insectivorous. For example, wild red jungle fowl (Gallus gallus) is known to eat ants and termites and juvenile wild turkeys eat approximately $60 \%$ of insects (Klasing, 2005). When farmed poultry have access to outdoor areas, they dedicate part of their time to searching for and ingesting live preys including insects (Józefiak et al., 2016; Schiavone et al., 2019). Table 4 and 5 report the main literature concerning the effects of insect-derived products inclusion in poultry diets. 
Table 4. Effects of Hermetia illucens products in gut health and microbiota modulation in poultry. ${ }^{1}$

\begin{tabular}{|c|c|c|c|c|c|c|}
\hline \multirow{2}{*}{$\begin{array}{l}\text { Poultry species } \\
\text { [IBW-FBW, g] } \\
\text { \{no. days }\end{array}$} & \multirow[t]{2}{*}{$\begin{array}{l}\text { Insect } \\
\text { [form] }\end{array}$} & \multicolumn{2}{|c|}{$\begin{array}{l}\text { Insect composition } \\
(\% \text { DM) }\end{array}$} & \multirow[t]{2}{*}{$\begin{array}{l}\% \text { insect } \\
\text { inclusion }\end{array}$} & \multirow[t]{2}{*}{ Gut health and microbiota } & \multirow[t]{2}{*}{ Reference } \\
\hline & & $\mathrm{CP}$ & $\mathrm{CL}$ & & & \\
\hline $\begin{array}{l}\text { Laying hens (Lohmann } \\
\text { Brown Classic) } \\
{[1,410-\text { no data] }\{168\}}\end{array}$ & HIL [DF] & 60.0 & 9.0 & $7.3,14.6$ & $\begin{array}{l}\text { In the duodenum, villi height and villi/crypt ratio were lower in } \\
\text { both HIL groups than in control. In ileum, only the villi height was } \\
\text { reduced in birds fed the highest level of HIL. }\end{array}$ & $\begin{array}{l}\text { Moniello et al. } \\
\text { (2019) }\end{array}$ \\
\hline $\begin{array}{l}\text { Laying hens (Lohmann } \\
\text { Brown Classic) } \\
{[1,780-2,009]\{147\}}\end{array}$ & HIL [DF] & 62.7 & 4.7 & 17 & $\begin{array}{l}\text { Increased relative abundance of Elusimicrobia, Lentisphaerae } \\
\text { and Cyanobacteria and decreased Fusobacteria. The HIL group } \\
\text { showed a higher villi height in the duodenum, while the opposite } \\
\text { happened in the jejunum and the ileum. Only in the ileum, higher } \\
\text { crypt depth in the HIL group than in the SBM. }\end{array}$ & $\begin{array}{l}\text { Borrelli et } \\
\text { al. (2017); } \\
\text { Cutrignelli et al. } \\
(2018)\end{array}$ \\
\hline $\begin{array}{l}\text { Broiler chickens (Ross } \\
308) \\
{[40.2-2,278]\{35\}}\end{array}$ & HIL [DF] & 55.3 & 18.0 & $5,10,15$ & $\begin{array}{l}\text { The HIL } 15 \% \text { showed a lower villus height, a higher crypt depth } \\
\text { and a lower villus height-to-crypt depth ratio than the other } \\
\text { groups. Caecal digesta analysis of HIL } 15 \% \text { birds displayed } \\
\text { significant increase of the relative abundance of Proteobacteria } \\
\text { phylum than HIL } 10 \% \text {. Characteristic microbiota for } 5 \% \text { HIL: } \\
\text { L-Ruminococcus (Lachnospiraceae family), Faecalibacterium, } \\
\text { Blautia and Clostridium genera were found to be characteristic } \\
\text { in caecal microbiota. Characteristic microbiota for } 10 \% \text { HIL: } \\
\text { Lactobacillus and Ruminococcus and Bacteroides, Roseburia. } \\
\text { Characteristic microbiota for } 15 \% \text { HIL: Helicobacter genera. } \\
\text { Lower mucin in small and large intestine of chicken fed } 10 \text { and } \\
15 \% \text { addition of HIL compared to CTRL. }\end{array}$ & $\begin{array}{l}\text { Biasato et al. } \\
\text { (2020a); Dabbou } \\
\text { et al. (2018) }\end{array}$ \\
\hline $\begin{array}{l}\text { Broiler chickens (Ross } \\
308) \\
{[42-2,101]\{35\}}\end{array}$ & HIL [FF] & 40.4 & 33.5 & 0.2 & $\begin{array}{l}\text { Crop: increase in Clostridium coccoides - Eubacterium rectale } \\
\text { cluster and Lactobacillus spp.IEnterococcus spp. Ileum: } \\
\text { increase in C. coccoides - E. rectale cluster and decrease } \\
\text { in Lactobacillus spp./Enterococcus spp. Caeca: increase in } \\
\text { Bacteroides-Prevotella cluster, Streptococcus spp./Lactococcus } \\
\text { spp., C. coccoides - E. rectale cluster and Lactobacillus spp.I } \\
\text { Enterococcus spp. }\end{array}$ & $\begin{array}{l}\text { Józefiak et al. } \\
\text { (2018) }\end{array}$ \\
\hline $\begin{array}{l}\text { Broiler chicken (Ross } \\
\text { 308) } \\
{[817.8-3,751.3]\{27\}}\end{array}$ & HIF & - & - & $3.43,6.87$ & No influence on gut morphometric indexes & $\begin{array}{l}\text { Schiavone et al. } \\
(2018)\end{array}$ \\
\hline $\begin{array}{l}\text { Muscovy ducks } \\
\text { (Cairina moschata } \\
\text { domestica) } \\
{[70.4-2,554]\{47\}}\end{array}$ & HIL [DF] & 56.7 & 10.7 & $3,6,9$ & No effect on gut morphology & $\begin{array}{l}\text { Gariglio et al. } \\
\text { (2019) }\end{array}$ \\
\hline $\begin{array}{l}\text { Turkey (B.U.T. } 6 \\
\text { AVIAGEN) } \\
{[179-1,396]\{35\}}\end{array}$ & HIF & - & - & $2.5,5$ & Decrease of Enterobacteriaceae counts & $\begin{array}{l}\text { Sypniewski et al. } \\
(2020)\end{array}$ \\
\hline
\end{tabular}


Table 5. Effects of Tenebrio molitor, Shelfordella lateralis and Zophobas morio meals in gut health and microbiota modulation in poultry. ${ }^{1}$

\begin{tabular}{|c|c|c|c|c|c|c|}
\hline \multirow{2}{*}{$\begin{array}{l}\text { Poultry species } \\
\text { [IBW-FBW, g] } \\
\text { \{no. days }\end{array}$} & \multirow[t]{2}{*}{$\begin{array}{l}\text { Insect } \\
\text { [form] }\end{array}$} & \multicolumn{2}{|c|}{$\begin{array}{l}\text { Insect composition } \\
\text { (\% DM) }\end{array}$} & \multirow[t]{2}{*}{$\begin{array}{l}\% \text { insect } \\
\text { inclusion }\end{array}$} & \multirow[t]{2}{*}{ Gut health and microbiota } & \multirow[t]{2}{*}{ Reference } \\
\hline & & $\mathrm{CP}$ & CL & & & \\
\hline $\begin{array}{l}\text { Broiler chickens (Ross } \\
308) \\
{[42-2,122]\{35\}}\end{array}$ & TMM [FF] & 47.0 & 29.6 & $0.2,0.3$ & $\begin{array}{l}\text { Caeca: TML } 0.2 \% \text { tended to show highest relative abundance } \\
\text { of the family Ruminococcaceae and Lactobacillus reuteri. } \\
\text { Significant increase in level of Clostridia. }\end{array}$ & $\begin{array}{l}\text { Józefiak et al. } \\
\text { (2020) }\end{array}$ \\
\hline $\begin{array}{l}\text { Broiler chickens (Ross } \\
308) \\
{[42-2,127]\{35\}}\end{array}$ & TMM [FF] & 56.3 & 25.3 & 0.2 & $\begin{array}{l}\text { Crop: decrease in Bacteroides-Prevotella cluster. lleum: } \\
\text { increase in Clostridium coccoides - Eubacterium rectale and } \\
\text { Lactobacillus spp./ Enterococcus spp. Caeca: increase in C. } \\
\text { coccoides - E. rectale. }\end{array}$ & $\begin{array}{l}\text { Józefiak et al. } \\
\text { (2018) }\end{array}$ \\
\hline $\begin{array}{l}\text { Broiler chickens (Ross } \\
\text { 708) } \\
\text { [no data-2,309] }\{40\}\end{array}$ & TMM [FF] & 55.3 & 25.1 & $5,10,15$ & No effect on gut morphology. & $\begin{array}{l}\text { Biasato et al. } \\
\text { (2017) }\end{array}$ \\
\hline $\begin{array}{l}\text { Free-range broiler } \\
\text { chickens } \\
\text { [716-no data] }\{53\}\end{array}$ & TMM [FF] & 55.3 & 25.1 & 7.5 & $\begin{array}{l}\text { Significant increase of the relative abundances of Firmicutes } \\
\text { and decrease of Bacteroidetes phyla. No effect on gut } \\
\text { morphology. Higher relative abundance of Clostridium, } \\
\text { Oscillospira, Ruminococcus, Coprococcus and Sutterella genera } \\
\text { compared to CTRL. }\end{array}$ & $\begin{array}{l}\text { Biasato et al. } \\
\text { (2018a) }\end{array}$ \\
\hline $\begin{array}{l}\text { Broiler chickens (Ross } \\
\text { 708) } \\
\text { [no data- } 3,641]\{53\}\end{array}$ & TMM [FF] & 57.5 & 30.7 & $5,10,15$ & $\begin{array}{l}\text { TMM } 15 \% \text { showed lower villus height, higher crypt depth, and } \\
\text { lower villus height to crypt depth ratio compared to CLRL and } \\
\text { TMM 5\%. }\end{array}$ & $\begin{array}{l}\text { Biasato et al. } \\
\text { (2018b) }\end{array}$ \\
\hline $\begin{array}{l}\text { Broiler chickens (Ross } \\
308) \\
{[42-2,076]\{35\}}\end{array}$ & SLI [FF] & 54.6 & 26.1 & $\begin{array}{l}0.05,0.1 \\
0.2\end{array}$ & $\begin{array}{l}\text { Crop: increase in Clostridium leptum subgroup. Ileum: increase } \\
\text { in C. coccoides - E. rectale cluster and Lactobacillus spp./ } \\
\text { Enterococcus spp. Ceca: increase in Bacteroides-Prevotella } \\
\text { cluster. }\end{array}$ & $\begin{array}{l}\text { Józefiak et al. } \\
\text { (2018) }\end{array}$ \\
\hline $\begin{array}{l}\text { Broiler chickens (Ross } \\
308) \\
{[42-2,122]\{35\}}\end{array}$ & ZMM [FF] & 49.3 & 33.6 & $0.2,0.3$ & $\begin{array}{l}\text { Caeca: ZML } 0.2 \% \text { resulted in an increase in relative abundance } \\
\text { of the Actinobacteria, including the family Bifidobacteriaceae, } \\
\text { with the highest relative abundance of genus Bifidobacterium } \\
\text { pseudolongum. ZML } 0.2 \% \text { resulted in an increase in the number } \\
\text { of Lactobacillus agilis. }\end{array}$ & $\begin{array}{l}\text { Józefiak et al. } \\
\text { (2020) }\end{array}$ \\
\hline
\end{tabular}

On the one hand, the effects of dietary insect meals inclusion on GIT morphometry in poultry, the results are often inconsistent. For instance, a decrease in the villi height, crypt depth and villi/crypt ratio was reported in the GIT segments (duodenal, jejunal and ileum) of laying hens (Cutrignelli et al., 2018; Moniello et al., 2019) and broilers (Dabbou et al., 2018) fed with HI especially when the inclusion levels surpassed $10 \%$. On the contrary, no histopathological changes were reported for Muscovy ducks (Gariglio et al., 2019) or broiler chickens (Biasato et al., 2018a) fed HI larva meal or for chickens fed TM meal (Biasato et al., 2016, 2017, 2018b). The use of insectderived oils/fats did not seem to affect the GIT morphology (Schiavone et al., 2018; Sypniewski et al., 2020).
On the other hand, dietary insects consistently modulate the microbiota populations in the GIT of poultry, but it may vary depending on the considered gut tract, the insect species or the level of insect inclusion (Benzeriha et al., 2019; Józefiak et al., 2018, 2020). Low levels of insect meals in poultry diets diversified the GIT microflora and increased the bacteria with positive effects on gut health (Józefiak et al., 2019a). However, levels higher than 10\% (and in particular 15\%) of insect meal inclusion seemed to reduce microbial complexity and richness in beneficial bacteria including those with mucolytic activity (Biasato et al., 2019a, 2020a). Following the ingestion of $0.2 \%$ of defatted TM, potentially pathogenic bacteria, such as the Bacteroides-Prevotella cluster, reduced in crops and caeca, while the ileum showed an increase in Lactobacillus spp./ 
Enterococcus spp. (Benzertiha et al., 2019; Józefiak et al., 2018). An increase in butyrate producing bacteria, such as the Clostridium coccoides - Eubacterium rectale cluster and the Clostridium leptum subgroup, was observed in broiler fed $0.2 \%$ of full fat $\mathrm{HI}$ in all the GIT and ileum, respectively (Józefiak et al., 2018).

Similar results were found in broilers fed 0.2 and $0.3 \%$ of TM or ZM full fat meals where Bacteroides-Prevotella cluster decreased in the caeca and a decrease in Clostridium perfringens counts decreased in groups treated with TM (0.2 and $0.3 \%)$ and ZM (0.2\%). In contrast, C. perfringens counts were increased in the birds fed $0.3 \%$ ZM resulting in a negative effect as this very pathogenic bacteria causes necrotic enteritis in poultry (Benzertiha et al., 2019).

Similarly, low inclusion levels $(0.2,0.3 \%)$ of TM and ZM in broiler chicken also improved caecal commensal microbiota with an increase in Clostridiales and particularly Lactobacillales and Bifidobacteriaceae with Bifidobacterium pseudolongum showing the highest abundance in the caecum digesta of birds fed 0.2\% ZM (Józefiak et al., 2020).

The dietary inclusion of $7.5 \%$ of full fat TM larva meal positively modulated the gut microbiota of free-range broiler chickens, inducing an increase in Firmicutes and a decrease in Bacteroidetes, but did not influence the mucin composition (Biasato et al., 2018a).

Insect meal was also shown to positively modulate the gut microbiota composition of laying hens. Borrelli et al (2017), for instance, indicated that the total substitution of SBM by defatted $\mathrm{HI}$ larvae increased the relative abundance of Elusimicrobia, Lentisphaerae and Cyanobacteria and decreased Fusobacteria, compared with SBM-fed laying hens. These changes were correlated with the production of butyric acid in the caeca, potentially linked to chitin degradation.

Dietary oil replacement by insect fat also influenced the microbiota as shown in turkey where total substitution of soybean oil (SBO) by HI fat reduced the proliferation of potentially pathogenic bacteria (i.e. Enterobacteriaceae spp.) (Sypniewski et al., 2020).

The modulation of the animal microbiota may be due to antimicrobial peptides (AMPs) produced by the insects introduced in the animal diet (Józefiak and Engberg, 2017). The addition of 2 AMPs (A3 and P5) to the chicken diet showed beneficial effects not only on growth performance and nutrient retention, (Choi et al., 2013a,b) but also on the histomorphology (dose-dependent increase in villi height and depth) and intestinal microflora through a decrease in the population of anaerobic bacteria in the ileal and caecal digesta. The same was true of chicken fed with a cecropin hybrid which showed increased villus height and villus height: crypt depth ratio, but showed a negative effect on the crypt depth of the duodenum and ileum and decreased total aerobic bacteria in the jejunal and caecal digesta (Wen and $\mathrm{He}, 2012$ ).

\section{Pigs and rabbits}

Literature on the influence of insect products on the microbiota and GIT health of pigs and rabbits is scarce as evident from Table 6. The somehow controversial results may be due to differences in composition of the used insect products.

Spranghers et al. (2018) did not observe any difference in the histo-morphological traits or in the bacterial count in the intestinal segments of weaned pigs fed full fat or defatted HI meal. Nevertheless, as an increase in lauric acid was found in all the gut segments of piglets fed HI meal, with significant differences between pigs fed $8 \%$ full fat $\mathrm{HI}$ meal compared to all the other treatments in the digestive tract compartments, the authors suggested a possible dosedependent antibacterial effect (Spranghers et al., 2018).

Yu et al. $(2019,2020 \mathrm{a})$ highlighted that the inclusion of a full fat HI larvae meal in finishing diets for pigs induced changes in the bacterial composition of the gut that were correlated to an enhanced colonic mucosal immune homeostasis. They suggested a prebiotic effect of low levels (2\%) of HI meal inclusion, likely due to chitin. Their results showed an increase in the abundance of health-promoting bacteria, such as Lactobacillus and Bifidobacterium, which are known to preserve the integrity of the intestine lining. At the same time, they also reported an increase in the abundance of butyrate-producing bacteria (Roseburia, Pseudobutyrivibrio and Faecalibacterium) and in the number of Clostridium XIVa clusters in the colon, with a consequent significant increase in the production of butyrate and SCFAs. As far as bacteria or bacterial metabolites with potential negative effects are concerned, their results showed a decrease in Streptococcus sp., Escherichia coli and in the metabolites involved in amino acids metabolism. The same authors (Yu et al., 2020b) also reported an increase in the relative weight of the small intestine of piglets fed 2 and $4 \%$ of $\mathrm{HI}$ meal and in the villus height in the jejunum of piglets fed $2 \%$ of $\mathrm{HI}$ meal, thus suggesting a promoting effect on gut development and metabolism. In contrast, Biasato et al. (2019b) reported no effect on the intestinal morphology of pigs fed HI defatted meal.

Feeding weaning piglets with an inclusion of up to $10 \%$ of defatted HI larvae meal had a positive effect on the caecal microbiota and the small intestine mucin composition, showing a modulation of the potentially beneficial bacteria and a preservation of the mature mucin secretory 
Table 6. Effects of insect products in gut health and microbiota modulation in pigs and rabbits. ${ }^{1}$

\begin{tabular}{|c|c|c|c|c|c|c|c|c|}
\hline \multirow[t]{2}{*}{$\begin{array}{l}\text { Animal } \\
\text { [IBW-FBW, kg] } \\
\text { \{no. days }\end{array}$} & \multirow[t]{2}{*}{$\begin{array}{l}\text { Insect } \\
\text { [form] }\end{array}$} & \multicolumn{2}{|c|}{ 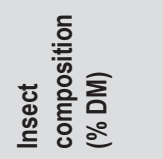 } & \multirow{2}{*}{ 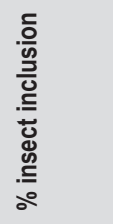 } & \multirow{2}{*}{ 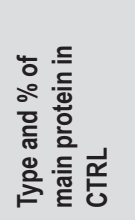 } & \multirow{2}{*}{ 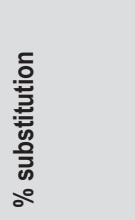 } & \multirow[t]{2}{*}{ Gut health and microbiota } & \multirow[t]{2}{*}{ Reference } \\
\hline & & $\mathrm{CP}$ & CL & & & & & \\
\hline \multirow[t]{2}{*}{$\begin{array}{l}\text { Weaning pigs } \\
{[6.1 \text {-no data] }\{15\}}\end{array}$} & HIL [FF] & 42.01 & 42.13 & 4,8 & $\begin{array}{l}\text { Toasted } \\
\text { soybeans: } \\
12 \%\end{array}$ & $\begin{array}{l}50 \text { and } \\
100 \%\end{array}$ & $\begin{array}{l}\text { No effects on gut morphology. Increase in lauric } \\
\text { acid in gut segment of pig fed } 8 \% \text { FF HIL }\end{array}$ & $\begin{array}{l}\text { Spranghers et al. } \\
(2018)\end{array}$ \\
\hline & HIL [DF] & 62.84 & 8.06 & 5.42 & & $72 \%$ & & \\
\hline $\begin{array}{l}\text { Weaning piglets } \\
{[7.9-17.6]\{28\}}\end{array}$ & HIL [FF] & 37.92 & 38.48 & $1,2,4$ & FM: $4 \%$ & $\begin{array}{l}25,50 \text { and } \\
100 \%\end{array}$ & $\begin{array}{l}\text { Increase of villus height in the jejunum of piglets } \\
\text { fed } 2 \% \text { HIL }\end{array}$ & $\begin{array}{l}\text { Yu et al. } \\
\text { (2020a,b) }\end{array}$ \\
\hline $\begin{array}{l}\text { Weaning pigs } \\
{[6.1-32.4]\{61\}}\end{array}$ & HIL [DF] & 59.0 & 8.97 & 5,10 & $\begin{array}{l}\text { SBM: } 20 \% \\
\text { (phase } \\
\text { I); } 18.5 \% \\
\text { (phase II) }\end{array}$ & $\begin{array}{l}\text { Phase I: } 30 \\
\text { and } 60 \% \text {; } \\
\text { Phase II: } \\
32 \text { and } \\
65 \%\end{array}$ & $\begin{array}{l}\text { No effects on gut morphology. Increase of } \\
\beta \text { diversity in HIL fed groups. Increase in } \\
\text { SCFAs producing bacteria. Decrease in jejunal } \\
\text { inflammation. Increase in neutral mucins }\end{array}$ & $\begin{array}{l}\text { Biasato et al. } \\
\text { (2019b, 2020b) }\end{array}$ \\
\hline $\begin{array}{l}\text { Finishing pigs } \\
{[76.0-116]\{46\}}\end{array}$ & HIL [FF] & 37.92 & 38.48 & 4,8 & $\begin{array}{l}\text { SBM: } \\
16.98 \%\end{array}$ & $\begin{array}{l}18.4 \text { and } \\
36.7 \%\end{array}$ & $\begin{array}{l}\text { Increase in Lactobacillus, Pseudobutyrivibrio, } \\
\text { Roseburia, and Faecalibacterium. Decrease in } \\
\text { Streptococcus }\end{array}$ & Yu et al. (2019) \\
\hline $\begin{array}{l}\text { Rabbits } \\
{[1.05-2.9]\{41\}}\end{array}$ & $\begin{array}{l}\text { HIF and } \\
\text { TMO }\end{array}$ & & & $0.75,1.5$ & SBO: $1.5 \%$ & $\begin{array}{l}50 \text { and } \\
100 \%\end{array}$ & No effects on gut morphology & $\begin{array}{l}\text { Gasco et al. } \\
(2019 b)\end{array}$ \\
\hline
\end{tabular}

${ }^{1} \mathrm{CL}=$ crude lipid; $\mathrm{CP}=$ crude protein; $\mathrm{CTRL}=$ control diet; $\mathrm{DF}=$ defatted; $\mathrm{DM}=$ dry matter; $\mathrm{FBW}$ = final body weight; $\mathrm{FF}$ = full fat; HIL = Hermetia illucens larvae meal; HIF = Hermetia illucens fat; IBW = initial body weight; SBM = soybean meal; SBO = soybean oil; SCFAs = short chain fatty acids; TMO = Tenebrio molitor oil.

architecture together with an attenuation of jejunal inflammation associated with an increased proportion of SCFA-producing bacteria in the caecal microbiota (Biasato et al., 2020b).

The dietary ingestion of HI and TM fats in substitution of 50 and $100 \%$ of soybean oil in the diets of growing rabbits did not influence the gut morphometry or alter the liver functions (Gasco et al., 2019b), although a positive effect on microbiota has been suggested (Dabbou et al., 2020). Indeed, an increase in the relative abundance of Bacteroides, Clostridium, Akkermansia and Ruminococcus has been observed. Akkermansia has been indicated as being able to degrade the mucin in the intestine, with a consequent production of SCFAs and consequent positive effects on gut health. Ruminococcus are also butyrate producing bacteria that contribute to the positive effect on the caecal microbiota of rabbits (Dabbou et al., 2020).

\section{Immunological status}

Beside their nutritional interest, insects contain biological active components such as chitin, which is a structural polysaccharide forming the outer shell of crustaceans and the exoskeleton of insects. It has been shown that crustacean chitin and chitin derivatives activate and boost the innate immune response of animals (Ringø et al., 2012) and its seems that insect chitin may play a similar role (Józefiak and Engberg, 2017; Lee et al., 2008).

\section{Fish and crustaceans}

In fish, dietary crustacean chitin and chitosan were potent immunostimulants and improved bacterial and parasitical disease resistance (Esteban et al., 2001; Lee et al., 2008; Shanthi Mari et al., 2014). However, few studies have investigated the effects of insects on the crustaceans and fish immune system (Table 7, 8 and 9). In crustaceans, dietary TM significantly increased both the total hemocyte counts and phenoloxidase activity of the Pacific white 
Table 7. Effects of Hermetia illucens meals on antioxidant enzymes, immune parameters in crustacean and fish. ${ }^{1}$

\begin{tabular}{|c|c|c|c|c|c|c|c|c|c|}
\hline \multirow{2}{*}{$\begin{array}{l}\text { Animal } \\
\text { [IBW-FBW, g] } \\
\text { \{no. days }\end{array}$} & \multirow[t]{2}{*}{$\begin{array}{l}\text { Insect } \\
\text { [form] }\end{array}$} & \multicolumn{2}{|c|}{$\begin{array}{l}\text { Insect composition } \\
\text { (\% DM) }\end{array}$} & \multirow[t]{2}{*}{$\begin{array}{l}\% \text { insect } \\
\text { inclusion }\end{array}$} & \multirow{2}{*}{$\begin{array}{l}\text { Type and \% of } \\
\text { main protein in } \\
\text { CTRL diet }\end{array}$} & \multirow[t]{2}{*}{$\begin{array}{l}\% \text { of } \\
\text { substitution }\end{array}$} & \multirow[t]{2}{*}{ Antioxidant enzymes } & \multirow[t]{2}{*}{ Immune parameters } & \multirow[t]{2}{*}{ Reference } \\
\hline & & $\mathrm{CP}$ & $\mathrm{CL}$ & & & & & & \\
\hline $\begin{array}{l}\text { Marron (Cherax cainii) } \\
{[65-89]\{60\}}\end{array}$ & HIL & - & - & 12,11 & $\begin{array}{l}\text { FM: } 41 \% \text { or PBP: } \\
39 \%\end{array}$ & 22,19 & & $\begin{array}{l}\text { Increased lysozyme, total haemocyte counts, } \\
\text { increased IL } 1 \beta \text {, IL8, IL10, IL17F and TNFa } \\
\text { expression in intestine }\end{array}$ & $\begin{array}{l}\text { Foysal et al. } \\
(2019)\end{array}$ \\
\hline $\begin{array}{l}\text { Zebrafish (Danio rerio) } \\
{[2-21 \mathrm{dps}]\{19\}}\end{array}$ & HIP [FF] & - & - & $10.5,21$ & FM: $42 \%$ & 25,50 & & $\begin{array}{l}\text { Transient increase in HSP70 at } 14 \text { dps then } \\
\text { significantly lower in HIP } 10.5 \text { and } 21 \% \text { than in } \\
\text { ctrl fish, higher TNFa and IL6 at } 21 \% \text { HIP }\end{array}$ & $\begin{array}{l}\text { Zarantoniello et } \\
\text { al. (2018) }\end{array}$ \\
\hline $\begin{array}{l}\text { Jian carp (Cyprinus } \\
\text { carpio, var Jian) } \\
{[35-110]\{59\}}\end{array}$ & HIL [DF] & - & - & $\begin{array}{l}2.6,5.3 \\
7.9,10.6 \%\end{array}$ & FM: $10 \%$ & $\begin{array}{l}25,50,75 \\
100\end{array}$ & $\begin{array}{l}\text { Reduced cholesterol; no effect on serum } \\
\text { SOD or MDA, increased serum CAT; more } \\
\text { apoptotic hepatocytes in fish fed HIL } 100 \%\end{array}$ & $\begin{array}{l}\text { At } \mathrm{HI}>75 \% \text {, enhanced hepatic HSP70 gene } \\
\text { expression suggesting induced stress }\end{array}$ & Li et al. $(2017 a, b)$ \\
\hline $\begin{array}{l}\text { Siberian sturgeon, } \\
\text { (Acipenser baerii), } \\
{[24-159]\{118\}}\end{array}$ & HIL [DF] & 65.8 & 4.24 & $18.5,37.5$ & FM: $70 \%$ & 25,50 & $\begin{array}{l}\text { Alteration of hepatic oxidative stress } \\
\text { biomarkers (increased SOD, GR, decreased } \\
\text { GPx at } 37.5 \% \text { ). SOD, GR, EROD and GST } \\
\text { increased in kidney of fish fed } 37.5 \% \text { HIL }\end{array}$ & & $\begin{array}{l}\text { Caimi et al. } \\
\text { (2020) }\end{array}$ \\
\hline $\begin{array}{l}\text { Yellow cattish } \\
\text { (Pelteobagrus fulvidraco) } \\
{[1.5-48.5]\{65\}}\end{array}$ & HIL [FF] & 47 & 17.7 & $\begin{array}{l}5.5,10.8 \\
16.5,22.3 \\
34.3,46.2 \\
58.5\end{array}$ & FM: $40 \%$ & $\begin{array}{l}13,25,37 \\
48,68,85 \\
100\end{array}$ & $\begin{array}{l}\text { Increased serum SOD at } 10.8 \% \text { inclusion. } \\
\text { Hepatopancreas SOD not affected }\end{array}$ & $\begin{array}{l}\text { Tendency for increased lysozyme and } \\
\text { phagocytosis activities at } 5.5 \text { and } 10.8 \% \\
\text { inclusion levels }\end{array}$ & Xiao et al. (2018) \\
\hline $\begin{array}{l}\text { Rainbow trout } \\
\text { (Oncorhynchus mykiss) } \\
{[137-300]\{98\}}\end{array}$ & HIP [FF] & 39 & 41.9 & $10.5,21$ & FM: $42 \%$ & 25,50 & No difference in cholesterol or hepatic GR & $\begin{array}{l}\text { HSP70 increase at } 21 \% \text { HIP; increased IL10 } \\
\text { and TNFa in mid-intestine }\end{array}$ & $\begin{array}{l}\text { Cardinaletti et al. } \\
(2019)\end{array}$ \\
\hline $\begin{array}{l}\text { Rainbow trout }(0 . \\
\text { mykiss) } \\
{[179-540]\{78\}}\end{array}$ & HIL [FF] & 55.3 & 18 & 20,40 & FM: $60 \%$ & 25,50 & $\begin{array}{l}\text { Unchanged liver and kidney MDA, SOD, CAT, } \\
\text { GPx, GR, reduced SeGPx in liver and kidney, } \\
\text { increased GSH and EROD in liver, increased } \\
\text { GST in kidney }\end{array}$ & & Elia et al. (2018) \\
\hline $\begin{array}{l}\text { Atlantic salmon (Salmo } \\
\text { salar) } \\
{[49-143]\{56\}}\end{array}$ & HIL [DF] & - & - & 60 & $\begin{array}{l}\text { FM: } 35 \%+\text { SPC: } \\
29.6 \%\end{array}$ & 83 & $\begin{array}{l}\text { Elevated xenobiotic detoxification response in } \\
\text { intestine (cyp1a1 expression) }\end{array}$ & $\begin{array}{l}\text { Stimulation of regulatory T-cell activity; no } \\
\text { difference in anti-IPVN antibodies }\end{array}$ & $\begin{array}{l}\text { Li et al. (2019); } \\
\text { Belghit et al. } \\
\text { (2018) }\end{array}$ \\
\hline $\begin{array}{l}\text { Atlantic salmon (S. salar) } \\
{[1,400-2,550]\{56\}}\end{array}$ & HIL [DF] & 52 & 18 & 10,15 & FM: $10 \%$ & $66 ; 100$ & $\begin{array}{l}\text { down-regulated SOD and GPx expression in } \\
\text { LPS-triggered cells }\end{array}$ & $\begin{array}{l}\text { No effect on inflammation response to bacteria } \\
\text { and virus; antioxidant and stress response to } \\
\text { bacteria downregulated (SOD, GPx, HSP70, } \\
\text { C/EBPB, p38MAPK and TLR22) }\end{array}$ & $\begin{array}{l}\text { Stenberg et al. } \\
(2019)\end{array}$ \\
\hline $\begin{array}{l}\text { Atlantic salmon (S. salar) } \\
{[1,400-3,702]\{112\}}\end{array}$ & HIL [DF] & 52 & 18 & $5,10,15$ & FM: $10 \%$ & $33 ; 66 ; 100$ & & No effect on haemoglobin & $\begin{array}{l}\text { Belghit et al. } \\
\text { (2019) }\end{array}$ \\
\hline $\begin{array}{l}\text { Japanese sea bass } \\
\text { (Lateolabrax japonicus), } \\
{[14-58]\{56\}}\end{array}$ & HIL [DF] & 55.4 & 1.6 & $\begin{array}{l}5,10,15 \\
20\end{array}$ & FM: $25 \%$ & $\begin{array}{l}16,32,48 \\
64\end{array}$ & $\begin{array}{l}\text { no difference in serum CAT, GPx, SOD; lower } \\
\text { MDA }\end{array}$ & $\begin{array}{l}\text { No effect on complement, alcaline } \\
\text { phosphatase or lysozyme activity or on } \\
\text { concentration of intestinal inflammatory } \\
\text { cytokines }\end{array}$ & $\begin{array}{l}\text { Wang et al. } \\
(2019)\end{array}$ \\
\hline
\end{tabular}


Table 8. Effects of Tenebrio molitor larvae meal on antioxidant enzymes, immune parameters and resistance to bacterial diseases in crustacean and fish. ${ }^{1}$

\begin{tabular}{|c|c|c|c|c|c|c|c|c|c|c|}
\hline \multirow{2}{*}{$\begin{array}{l}\text { Animal } \\
\text { [IBW-FBW, g] } \\
\text { \{no. days\} }\end{array}$} & \multirow[t]{2}{*}{$\begin{array}{l}\text { Insect } \\
\text { [form] }\end{array}$} & \multicolumn{2}{|c|}{$\begin{array}{l}\text { Insect composition } \\
\text { (\% DM) }\end{array}$} & \multirow[t]{2}{*}{$\begin{array}{l}\% \text { insect } \\
\text { inclusion }\end{array}$} & \multirow{2}{*}{$\begin{array}{l}\text { Type and } \% \text { of } \\
\text { main protein in } \\
\text { CTRL diet }\end{array}$} & \multirow[t]{2}{*}{$\begin{array}{l}\% \text { of } \\
\text { substitution }\end{array}$} & \multirow[t]{2}{*}{$\begin{array}{l}\text { Antioxidant } \\
\text { enzymes }\end{array}$} & \multirow[t]{2}{*}{ Immune parameters } & \multirow[t]{2}{*}{ Resistance to diseases } & \multirow[t]{2}{*}{ Reference } \\
\hline & & $\mathrm{CP}$ & $\mathrm{CL}$ & & & & & & & \\
\hline $\begin{array}{l}\text { Pacific white shrimp } \\
\text { (Litopenaeus } \\
\text { vannamei) } \\
{[1.5-6]\{56\}}\end{array}$ & TMM [DF] & 74.8 & 12.6 & $\begin{array}{l}5,10,15 \\
20\end{array}$ & FM: $25 \%$ & $\begin{array}{l}25,50,75 \\
100\end{array}$ & & $\begin{array}{l}\text { Increased phenoloxidase activity and total } \\
\text { haemocyte counts; decreased bacterial } \\
\text { number }\end{array}$ & $\begin{array}{l}\text { Increased resistance to } \\
\text { Vibrio parahaemolyticus } \\
(55 ; 75 ; 84 ; 87 ; 86)\end{array}$ & $\begin{array}{l}\text { Motte et al. } \\
\text { (2019) }\end{array}$ \\
\hline $\begin{array}{l}\text { Mandarin fish } \\
\text { (Siniperca scherzeri) } \\
{[21-36]\{56\}}\end{array}$ & TMM [FF] & 52.5 & 34.1 & $10,20,30$ & FM: $65 \%$ & $11,22,32$ & $\begin{array}{l}\text { GPx increased } \\
\text { at } 30 \% ; \text { SOD not } \\
\text { affected }\end{array}$ & $\begin{array}{l}\text { Reduced cholesterol et } 30 \% \text {; lysozyme } \\
\text { increased, significantly at } 30 \% \text {; } \\
\text { myeloperoxidase not affected }\end{array}$ & & $\begin{array}{l}\text { Sankian et al. } \\
\text { (2018) }\end{array}$ \\
\hline $\begin{array}{l}\text { Yellow catfish } \\
\text { (Pelteobagrus } \\
\text { fulvidraco) } \\
\text { [10-no data] }\{35\}\end{array}$ & TMM [-] & & & $9,18,27$ & FM: $24 \%$ & $25,50,75$ & $\begin{array}{l}\text { Lower MDA; } \\
\text { increased plasma } \\
\text { SOD }\end{array}$ & $\begin{array}{l}\text { Enhanced immune (lysozyme, lgM); up- } \\
\text { regulation of hepcidin, MHC II and IL2 }\end{array}$ & $\begin{array}{l}\text { Enhanced resistance to } \\
\text { Edwardsiella ictaluri ( } 67 ; 70 \text {; } \\
74 ; 87 \%)\end{array}$ & Su et al. (2017) \\
\hline $\begin{array}{l}\text { Rainbow trout } \\
\text { (Oncorhynchus } \\
\text { mykiss) } \\
{[116-314]\{90\}}\end{array}$ & TMM [FF] & 51.9 & 23.6 & 25,50 & FM: $75 \%$ & 35,66 & $\begin{array}{l}\text { increase of intestinal } \\
\text { SOD, CAT, G6DP; } \\
\text { reduced MDA }\end{array}$ & $\begin{array}{l}\text { More rapid antibacterial activity } \\
\text { of complement and increased } \\
\text { myeloperoxidase and anti-protease } \\
\text { activities; no effect on inflammation or } \\
\text { lysozyme activity }\end{array}$ & & $\begin{array}{l}\text { Henry et al. } \\
\text { (2018b); Belforti } \\
\text { et al. (2015) }\end{array}$ \\
\hline $\begin{array}{l}\text { Sea trout (Salmo trutta) } \\
{[5-21]\{56\}}\end{array}$ & $\begin{array}{l}\text { TMM } \\
\text { [hydrolysed] }\end{array}$ & 47 & 29.6 & 10 & FM: $25 \%$ & 58 & & No change in IgM or lysozyme activity & & $\begin{array}{l}\text { Mikolajczak et al. } \\
\text { (2020) }\end{array}$ \\
\hline $\begin{array}{l}\text { European sea bass } \\
\text { (Dicentrarchus labrax) } \\
{[65]\{42\}}\end{array}$ & TMM [FF] & 51.9 & 23.6 & 25 & FM: $70 \%$ & 35 & & $\begin{array}{l}\text { Decreased inflammatory and stress- } \\
\text { related response (myeloperoxidase and } \\
\text { nitric oxide); increased anti-protease } \\
\text { activity. No effect on lysozyme or } \\
\text { complement }\end{array}$ & & $\begin{array}{l}\text { Henry et al. } \\
\text { (2018a,b); Gasco } \\
\text { et al. (2016) }\end{array}$ \\
\hline $\begin{array}{l}\text { Pearl gentian } \\
\text { grouper (Epinephelus } \\
\text { lanceolatus } \times \text { E. } \\
\text { fuscoguttatus) } \\
{[7-67]\{50\}}\end{array}$ & TMM [DF] & 65 & 3 & $\begin{array}{l}2.5,5,7.5 \\
10,12.5\end{array}$ & FM: $40 \%$ & $\begin{array}{l}6,12,18 \\
25,31\end{array}$ & $\begin{array}{l}\text { decreased SOD } \\
\text { and MDA at } 7.5 \% \text {, } \\
\text { increased GR at } 2.5 \%\end{array}$ & & $\begin{array}{l}\text { Better survival to Vibrio } \\
\text { harveyi with } 7.5 \% \text { TMM ( } 35 \text {; } \\
33 ; 30 ; 50 ; 10 ; 5 \%)\end{array}$ & $\begin{array}{l}\text { Song et al. } \\
(2018)\end{array}$ \\
\hline $\begin{array}{l}\text { Red seabream (Pagrus } \\
\text { major) } \\
{[24-34]\{56\}}\end{array}$ & TMM [DF] & 76.5 & 5.3 & 5,10 & FM: $50 \%$ & 10,20 & SOD not affected & & $\begin{array}{l}\text { Increased survival to } \\
\text { Edwarsiella tarda }(21 ; 55 ; \\
67 \%)\end{array}$ & Ido et al. (2019) \\
\hline
\end{tabular}

${ }^{1} \mathrm{CAT}=$ catalase $\mathrm{CL}=$ crude lipid; $\mathrm{CP}=$ crude protein; $\mathrm{CTRL}=$ control diet; $\mathrm{DF}=$ defatted; $\mathrm{FBW}=$ final body weight; $\mathrm{FF}$ = full fat; $\mathrm{FM}$ = fishmeal; $\mathrm{GPx}=$ glutathione peroxidase; $\mathrm{GR}=$ glutathione reductase; $\mathrm{G} 6 \mathrm{DP}=$ anti oxidative enzyme; IBW = initial body weight; IgM = immunoglobulin M; IL2 = interleukin-2; MDA = malondialdehyde; MHC = major histocompatibility complex gene; SOD = superoxide dismutase; $\mathrm{TMM}=$ Tenebrio molitor larvae meal. 


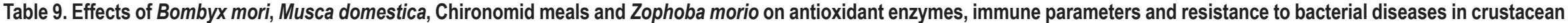
and fish. ${ }^{1}$

\begin{tabular}{|c|c|c|c|c|c|c|c|c|c|c|}
\hline \multirow{2}{*}{$\begin{array}{l}\text { Animal } \\
\text { [IBW-FBW, g] } \\
\text { \{no. days }\end{array}$} & \multirow[t]{2}{*}{$\begin{array}{l}\text { Insect } \\
\text { [form] }\end{array}$} & \multicolumn{2}{|c|}{$\begin{array}{l}\text { Insect composition } \\
\text { (\% DM) }\end{array}$} & \multirow[t]{2}{*}{$\begin{array}{l}\% \text { insect } \\
\text { inclusion }\end{array}$} & \multirow{2}{*}{$\begin{array}{l}\text { Type and } \% \text { of } \\
\text { main protein in } \\
\text { CTRL diet }\end{array}$} & \multirow[t]{3}{*}{$\begin{array}{l}\% \text { of } \\
\text { substitution }\end{array}$} & \multirow[t]{3}{*}{$\begin{array}{l}\text { Antioxidant } \\
\text { enzymes }\end{array}$} & \multirow[t]{2}{*}{ Immune parameters } & \multirow[t]{2}{*}{ Resistance to diseases } & \multirow[t]{2}{*}{ Reference } \\
\hline & & $\mathrm{CP}$ & $\mathrm{CL}$ & & & & & & & \\
\hline $\begin{array}{l}\text { Prawns (Litopenaeus } \\
\text { vannamei) } \\
{[0.6-2.4]\{30\}}\end{array}$ & BM & & & $\begin{array}{l}0.0125 \\
0.25,5 \\
\mu g / g\end{array}$ & FM: $24.5 \%$ & & & & $\begin{array}{l}\text { Increased survival to Vibrio } \\
\text { penaecida }(0 ; 90 ; 89.5 ; 100)\end{array}$ & Ali et al. (2018) \\
\hline $\begin{array}{l}\text { Prawns } \\
\text { (Marsupenaeus } \\
\text { japonicus) } \\
{[0.9-1.4]\{15\}}\end{array}$ & BM [DF] & & & $\begin{array}{l}0.001 \\
0.01,0.1\end{array}$ & FM: $20 \%$ & & & & $\begin{array}{l}\text { Increased survival to } V \text {. } \\
\text { penaecida }(0 ; 73 ; 77 ; 76)\end{array}$ & \\
\hline $\begin{array}{l}\text { Asian swamp eel } \\
\text { (Monopterusalbus) } \\
{[27-31]\{56\}}\end{array}$ & MDL [whole] & 64 & 24.3 & $\begin{array}{l}1 \text { day every } \\
3(1 \mathrm{~d} / 3) \\
\text { or } 7 \text { days } \\
(1 \mathrm{~d} / 7)\end{array}$ & FM: $45 \%$ & & & $\begin{array}{l}\text { HSP70 and IL1 } \beta \text { downregulated, no } \\
\text { difference in IgM }\end{array}$ & $\begin{array}{l}\text { Better resistance to } \\
\text { Aeromonas hydrophila ( } 73 \text {; } \\
93 \text { for } 1 \mathrm{~d} / 3 ; 83 \% \text { for } 1 \mathrm{~d} / 7 \text { ) }\end{array}$ & $\begin{array}{l}\text { Xiang et al. } \\
(2019)\end{array}$ \\
\hline $\begin{array}{l}\text { Asian swamp eel (M. } \\
\text { albus) } \\
{[30-58]\{40\}}\end{array}$ & MDL [DF] & 60 & 2.6 & $10,20,30$ & $70 \%$ earthworm & $\begin{array}{l}\text { not } \\
\text { isonitrogenous } \\
\text { and isolipidic }\end{array}$ & $\begin{array}{l}\text { Increased anti-oxidant } \\
\text { enzymes (SOD, GPx, } \\
\text { CAT) }\end{array}$ & $\begin{array}{l}\text { Increased lysozyme, acid and alkaline } \\
\text { phosphatase; lower serum triglycerides }\end{array}$ & $\begin{array}{l}\text { Increased survival to } A \text {. } \\
\text { hydrophila }(30 ; 37.5 ; 45 \text {; } \\
37.5)\end{array}$ & Pei et al. (2019) \\
\hline $\begin{array}{l}\text { Black carp } \\
\text { (Mylopharyngodon } \\
\text { piceus) } \\
\text { [72-no data] }\{60\}\end{array}$ & MDL [-] & & & 2.5 & $\begin{array}{l}\text { together with } 150 \\
\mathrm{mg} / \mathrm{kg} \text { carnitine }\end{array}$ & & $\begin{array}{l}\text { Increased serum GPx } \\
\text { and liver SOD,GPx } \\
\text { and CAT; reduced } \\
\text { MDA }\end{array}$ & Increased lysozyme and complement & $\begin{array}{l}\text { Improved resistance to } A \text {. } \\
\text { hydrophila }\end{array}$ & Ming et al. (2013) \\
\hline $\begin{array}{l}\text { Red seabream (Pagrus } \\
\text { major) } \\
{[26-n o \text { data] }\{60\}}\end{array}$ & $\begin{array}{l}\text { MD pupae } \\
{[\mathrm{FF}]}\end{array}$ & 50.6 & 21.9 & 5 & FM: $50 \%$ & 10 & & & $\begin{array}{l}\text { Increased resistance to } \\
\text { Edwardsiella tarda (0; } \\
100 \%)\end{array}$ & Ido et al. (2015) \\
\hline $\begin{array}{l}\text { Red seabream }(P . \\
\text { major) } \\
{[48-\text { no data] }\{10\}}\end{array}$ & & & & $0.75,7.5$ & & $1.5,15$ & & Increased phagocytic activity & & \\
\hline $\begin{array}{l}\text { Rainbow trout } \\
\text { (Oncorhynchus } \\
\text { mykiss) } \\
{[0.13-0.65]\{28\}}\end{array}$ & ChL [whole] & 66 & 9 & 100 & FM: $12.4 \%$ & & & $\begin{array}{l}\text { Higher proliferation and apoptotic } \\
\text { indexes in the proximal intestine, no } \\
\text { difference in distal intestine }\end{array}$ & & $\begin{array}{l}\text { Ostaszewska et } \\
\text { al. (2011) }\end{array}$ \\
\hline $\begin{array}{l}\text { Sea trout (Salmo trutta) } \\
{[5-21]\{56\}}\end{array}$ & $\begin{array}{l}\text { ZMM } \\
\text { [hydrolysed] }\end{array}$ & 49.3 & 33.6 & 10 & FM: $25 \%$ & 56 & & No change in IgM or lysozyme activity & & $\begin{array}{l}\text { Mikolajczak et al. } \\
(2020)\end{array}$ \\
\hline
\end{tabular}

${ }^{1} \mathrm{BM}=$ Bombyx mori; $\mathrm{CAT}=$ catalase $\mathrm{ChL}=$ Chironomidae frozen larvae; $\mathrm{CL}=$ crude lipid; $\mathrm{CP}=$ crude protein; $\mathrm{CTRL}=$ control diet; $\mathrm{DF}=$ defatted; $\mathrm{FBW}=$ final body weight; $\mathrm{FF}=$ full fat; $\mathrm{FM}=$ fishmeal; $\mathrm{GPx}=$ glutathione peroxidase HSP70 = heat shock proteins 70; IBW = initial body weight; IgM = immunoglobulin M; IL1 $\beta=$ interleukin 1 beta; MDA = malondialdehyde; MDL = Musca domestica larvae meal; SOD = superoxide dismutase; ZMM = Zophoba morio larvae meal. 
shrimp, Litopenaeus vannamei (Motte et al., 2019), and dietary HI increased lysozyme, total haemocyte counts and cytokine expression in the intestine of crayfish marron (C. cainii) (Foysal et al., 2019). In fish, only two studies have shown no effect of dietary insects on the immune system of fish (Mikołajczak et al., 2020; Wang et al., 2019). All other studies, concerning dietary inclusion of whole chironomid larvae or meals from HI, TM or MD, showed modulation of the fish immune system through a more rapid or increased antibacterial complement activity (Henry et al., 2018b; Ming et al., 2013), increased lysozyme (Ming et al., 2013; Pei et al., 2019; Sankian et al., 2018; Su et al., 2017), increased phagocytic activity (Ido et al., 2015) and increased myeloperoxidase (MPO) activity in rainbow trout (Henry et al., 2018b), but decreased MPO in European sea bass (Henry et al., 2018a), increased trypsin-inhibition (Henry et al., 2018a,b), increased alkaline phosphatase (Pei et al., 2019), increased IgM titres (Su et al., 2017), increased proliferation and apoptotic indexes of the proximal intestine (Ostazewska et al., 2011) and stimulation of T-cells (Li et al., 2019). As for the expression of the genes involved in immunity, and cytokines in particular, dietary insects induced an upregulation of hepcidin, major histocompatibility complex II (Su et al., 2017), HSP70 (Cardinaletti et al., 2019; Li et al., 2017a; Zarantoniello et al., 2018) pro-inflammatory cytokines, such as interleukin (IL) $1 \beta$, IL17F, tumour necrosis factor (TNF) $\alpha$ and IL6 expression (Foysal et al., 2019; Zarantoniello et al., 2018) anti-inflammatory cytokines such as IL10 (Foysal et al., 2019), IL2, a cytokine which contributes to the differentiation of T-cells (Su et al., 2017), while HSP-70 and the pro-inflammatory cytokine IL1 $\beta$ were down-regulated in swamp eel (Xiang et al., 2019). Some studies have shown no effect of dietary insects on inflammation or on the expression of inflammation-related cytokines (Henry et al., 2018b; Li et al., 2020; Stenberg et al., 2019), but inflammation has been observed to decrease in European sea bass, as suggested by the ceruloplasmin activity (Henry et al., 2018a). Dietary insects certainly affect the cytokines related to the inflammatory response, but this effect was not found to be consistent between fish species, and it is somewhat difficult to define their precise role. It has been suggested that chitin acts as a pathogenassociated molecular patterns by binding to pathogens recognition receptors and stimulating the production of several cytokines and immune mediators (Stenberg et al., 2019). Regarding the anti-oxidant and stress-response, an in vitro study showed that HI down-regulated the bacteria triggered in head-kidney cells of Atlantic salmon (Stenberg et al., 2019). Dietary insects have also been shown to modulate the hepatic or intestinal antioxidant response of fish (Caimi et al., 2020; Elia et al., 2018; Henry et al., 2018b; Ming et al., 2013; Pei et al., 2019; Sankian et al., 2018; Song et al., 2018; Su et al., 2017) and to increase the detoxification capacity in the distal intestine of fish, as suggested by the elevated expression of the Cyp1a1 gene in the intestine of Atlantic salmon (Li et al., 2019). However, this may be linked to potentially higher concentrations of heavy metals in IM, and the absence of effects on toxicity indicators (cell apoptosis or tissue regeneration) or on gut histology tended to infirm this hypothesis (Li et al., 2020).

\section{Poultry}

Diet is one of the factor affecting the immunological mechanism of poultry (Kaiser and Balic, 2015). Immunological effects of poultry fed insects products are reported in Table 10.

A recent study in broiler chickens showed that small amounts (0.2 and $0.3 \%)$ of TM and ZM significantly decreased IgM levels but up-regulated IL-2. Both dietary insects also decreased the weight of Bursa of Fabricius associated with the differentiation of B-lymphocytes. (Benzertiha et al., 2020). Moreover, insect oil extracted from both TM and ZM affected the expression of selected genes involved in immunological homeostasis, such as GIMAP5, a key regulator of hematopoietic integrity and lymphocyte homeostasis, Kierończyk et al. (2018).

The ingestion of low levels of HI (1, 2 and 3\%) also immunostimulated broilers by increasing the CD4+ T lymphocyte counts, serum lysozyme activity, spleen lymphocyte proliferation and phagocytic activity in a dosedependent manner (Lee et al., 2018).

Blood analyses of birds fed insect meals have shown that levels corresponding to about $1 \mathrm{~g} / \mathrm{d}$ of ingested chitin increased the globulin levels and decreased the albumin to globulin ratio indicating a better immune response (Bovera et al., 2015, 2018; Marono et al., 2017). Feeding laying hens with defatted $\mathrm{HI}$ also reduced triglycerides and cholesterol levels (Bovera et al., 2018). On the other hand, the inclusion of HI meal in jumbo quail diets increased the albumin/globulin ratio, which may have compromised the birds' immunity and caused plasma disorders (Mbhele et al., 2019). However, other researchers did not show any differences in blood traits following the ingestion of insect meals, thus suggesting the need to further study the mechanism of action (Biasato et al., 2016, 2017, 2018b; Dabbou et al., 2018; Elahi et al., 2020).

The partial substitution of SBO by HIL fat down-regulated the pro-inflammatory TNF- $\alpha$, while the total substitution reduced the proliferation of potentially pathogenic bacteria (i.e. Enterobacteriaceae spp.) and down-regulated the pro-inflammatory IL-6, thereby supporting the immune response of turkeys (Sypniewski et al., 2020). Dietary HIF however showed no effect on broiler chicken haematological traits (Schiavone et al., 2018). 
Table 10. Immunological status of poultry fed insect products. ${ }^{1}$

\begin{tabular}{|c|c|c|c|c|c|c|}
\hline \multirow[t]{2}{*}{$\begin{array}{l}\text { Poultry species [IBW- } \\
\text { FBW, kg] \{no. days\} }\end{array}$} & \multirow[t]{2}{*}{$\begin{array}{l}\text { Insect } \\
\text { species } \\
\text { and form }\end{array}$} & \multicolumn{2}{|c|}{$\begin{array}{l}\text { Insect } \\
\text { composition } \\
(\% \text { DM) }\end{array}$} & \multirow[t]{2}{*}{$\begin{array}{l}\% \text { insect } \\
\text { inclusion }\end{array}$} & \multirow[t]{2}{*}{ Immunological status } & \multirow[t]{2}{*}{ References } \\
\hline & & $\mathrm{CP}$ & $\mathrm{CL}$ & & & \\
\hline $\begin{array}{l}\text { Jumbo quails } \\
\text { [no data-223] }\{42\}\end{array}$ & HIL [DF] & 55.5 & 11.1 & $\begin{array}{l}2.5,5,7.5 \\
10\end{array}$ & Increase of albumin/globulin ratio. & Mbhele et al. (2019) \\
\hline $\begin{array}{l}\text { Laying hens (Hy-line Brown) } \\
{[1,410-1,857]\{140\}}\end{array}$ & HIL [DF] & 60.0 & 9.0 & $7.3,14.6$ & $\begin{array}{l}\text { Decrease in albumin/globulin ratio. Decrease in cholesterol and } \\
\text { triglycerides levels. }\end{array}$ & Bovera et al. (2018) \\
\hline $\begin{array}{l}\text { Laying hens Lohmann } \\
\text { Brown Classic } \\
{[1,790-1,890]\{140\}}\end{array}$ & HIL [DF] & 62.7 & 4.7 & 17 & Increase level of globulin. Decrease albumin/globulin ratio. & Marono et al. (2017) \\
\hline $\begin{array}{l}\text { Broiler chickens (Ross) } \\
\text { [no data-1,300] }\{30\}\end{array}$ & HIL [FF] & $\begin{array}{l}\text { no } \\
\text { data }\end{array}$ & $\begin{array}{l}\text { no } \\
\text { data }\end{array}$ & $1,2,3$ & $\begin{array}{l}\text { Increase in frequency of CD4+ T lymphocyte, serum lysozyme } \\
\text { activity, and spleen lymphocyte proliferation. }\end{array}$ & Lee et al. (2018) \\
\hline $\begin{array}{l}\text { Broiler chickens (Ross 308) } \\
{[70,7-2,554]\{35\}} \\
{[40.2-2,278]\{35\}}\end{array}$ & HIL [DF] & 55.3 & 18.0 & $5,10,15$ & $\begin{array}{l}\text { No differences in haematological traits. } \\
\text { No differences in histopathological examination. }\end{array}$ & $\begin{array}{l}\text { Dabbou et al. (2018); } \\
\text { Biasato et al. (2020a) }\end{array}$ \\
\hline $\begin{array}{l}\text { Muscovy ducks (Cairina } \\
\text { moschata domestica) } \\
{[70.4-2,554]\{47\}}\end{array}$ & HIL [DF] & 56.7 & 10.7 & $3,6,9$ & No influence on haematological traits. & Gariglio et al. (2019) \\
\hline $\begin{array}{l}\text { Broiler chickens (Ross } 308) \\
{[42-2,104]\{35\}}\end{array}$ & TMM [FF] & 47.0 & 29.6 & $0.2,0.3$ & $\begin{array}{l}\text { Significantly decreased IgM levels. Significant increase of IL-2 } \\
\text { and TNF- } \alpha \text { at } 0.3 \% \text { TMM. No significant changes in level of IgY, } \\
\text { IgA, and IL-6. Decreased of Bursa of Fabricius }\end{array}$ & $\begin{array}{l}\text { Benzertiha et al. } \\
(2020)\end{array}$ \\
\hline $\begin{array}{l}\text { Broiler chickens (Shaver } \\
\text { brown) } \\
{[1,760-3,470]\{32\}}\end{array}$ & TMM [FF] & 55.3 & 23.0 & 30 & $\begin{array}{l}\text { Decreased albumin/globulin ratio- } \\
\text { Increased aspartate aminotransferase and alanine } \\
\text { aminotransferase. }\end{array}$ & Bovera et al. (2015) \\
\hline $\begin{array}{l}\text { Broiler chickens (Ross } 708 \text { ) } \\
\text { [no data-2,309] }\{40\}\end{array}$ & TMM [FF] & 55.3 & 25.1 & $5,10,15$ & $\begin{array}{l}\text { Correlation between increasing TMM and changes in the } \\
\text { blood and serum parameters: increased erythrocytes level and } \\
\text { albumin, while the gamma glutamyl transferase decreased. }\end{array}$ & Biasato et al. (2017) \\
\hline $\begin{array}{l}\text { Broiler chickens (Ross } 308) \\
{[42-2,253 / 2,273]\{42\}}\end{array}$ & $\begin{array}{l}\text { TMM [FF] } \\
\text { fresh } \\
\text { TMM [FF] } \\
\text { dried }\end{array}$ & 20.15 & 11.49 & $2,4,8$ & No differences in haematological traits. & Elahi et al. (2020) \\
\hline $\begin{array}{l}\text { Broiler chickens (Ross } 708 \text { ) } \\
\text { [no data-3,641] }\{53\}\end{array}$ & TMM [FF] & 57.5 & 30.7 & $5,10,15$ & $\begin{array}{l}\text { No differences in histopathological examination. } \\
\text { Histopathological alterations varied from absent/minimal to } \\
\text { severe in spleen, thymus, bursa of Fabricius and liver for each } \\
\text { dietary treatment. }\end{array}$ & Biasato et al. (2018b) \\
\hline $\begin{array}{l}\text { Broiler chickens (Ross } 308) \\
{[42-2,122]\{35\}}\end{array}$ & ZMM [FF] & 49.3 & 33.6 & $0.2,0.3$ & $\begin{array}{l}\text { Significant decrease of } \lg Y \text { at } 0.2 \% \text { ZMM, } \operatorname{lgM} \text { at } 0.2 \text { and } \\
0.3 \% Z M M \text {. Significant increase of IL2. No significant changes } \\
\text { in level of IgA and TNF-a. Decreased of Bursa of Fabricius. }\end{array}$ & $\begin{array}{l}\text { Benzertiha et al. } \\
\text { (2020) }\end{array}$ \\
\hline $\begin{array}{l}\text { Broiler chickens (Ross } 308) \\
{[42-1,555 / 1,566]\{28\}}\end{array}$ & $\begin{array}{l}\text { TMO, } \\
\text { ZMO }\end{array}$ & - & - & 5 & $\begin{array}{l}\text { Liver: ZMO diet: the APOA1 gene was upregulated; TMO diet: } \\
\text { the HNF4A gene was downregulated; ZMO and TMO diets: the } \\
\text { GIMPA5 gene was significantly downregulated. }\end{array}$ & $\begin{array}{l}\text { Kieronczyk et al. } \\
\text { (2018) }\end{array}$ \\
\hline $\begin{array}{l}\text { Broiler chickens (Ross 308) } \\
{[817.8-3,751.3]\{27\}}\end{array}$ & HIF & - & - & $3.43,6.87$ & No influence in haematological traits. & $\begin{array}{l}\text { Schiavone et al. } \\
\text { (2018) }\end{array}$ \\
\hline $\begin{array}{l}\text { Turkey (B.U.T. } 6 \text {, AVIAGEN) } \\
{[179-1,398]\{35\}}\end{array}$ & HIF & - & - & $2.5,5$ & $\begin{array}{l}\text { Partial substitution of SBO: reduction of TNF-a concentration. } \\
\text { Total substitution of SBO: reduction of IL-6. }\end{array}$ & $\begin{array}{l}\text { Sypniewski et al. } \\
(2020)\end{array}$ \\
\hline
\end{tabular}

${ }^{1} \mathrm{APOA} 1$ = apolipoprotein $\mathrm{Al} ; \mathrm{CF}=$ crude fat; $\mathrm{CP}=$ crude protein; $\mathrm{DF}=$ defatted; $\mathrm{DM}=$ dry matter; FBW = final body weight; FF = full fat; GIMPA5 = guanosine triphosphatases of the immune-associated protein 5; HIL = Hermetia illucens larvae meal; HIF = Hermetia illucens fat; HNF4A = hepatocyte nuclear factor 4 alpha; IBW = initial body weight; IgA = immunoglobulin A; IgM = immunoglobulin M; IgY = immunoglobulin Y; IL-2 = interleukin-2; IL-6 = interleukin-6; SBO = soybean oil; $\mathrm{TMM}=$ Tenebrio molitor larvae meal; $\mathrm{TMO}=$ Tenebrio molitor oil; $\mathrm{TNF}=$ tumour necrosis factor-alpha; ZMM = Zophobas morio larvae meal; ZMO = Zophobas morio oil. 


\section{Pigs}

Immunological effects of pigs and rabbits fed insects products are reported in Table 11. Dietary HI larvae meal at levels varying between 3.5 and $10 \%$ had no effect on the haematological parameters of piglets (Biasato et al., 2019; Driemeyer, 2016). Indeed, these authors reported no major effects on the blood profile parameters, all of which fell within the physiological range for pigs, although a linear increase in monocytes and a quadratic response of neutrophils were observed (Biasato et al., 2019b). Dietary TM had no effect on the blood profile or immune system of weaned piglets (Ao et al., 2020). At dietary levels up to $6 \%$, TM meal did not affect immunoglobulin G (IgG) and immunoglobulin A (IgA) titres, but increased the serum insulin-like growth factor (Jin et al., 2016).

An increase in neutrophils was found in growing pigs fed diets with increasing levels of $\mathrm{HI}$ full fat larvae meal in partial and total substitution of FM (Chia et al. 2019), thus suggesting an immunostimulating activity of dietary HI. The authors ascribed the antimicrobial response to the high level of lauric acid in HI larva meal and speculated an increased protection effect against pathogens such as bacteria, viruses and fungi.

The beneficial effect of full fat HI meal (2 and 4\%) dietary inclusion on the immune homeostasis of piglets is linked to the increase in serum anti-inflammatory cytokines IL-10 and IgA and simultaneous decrease in the pro-inflammatory cytokine IFN- $\gamma$ (Yu et al. 2020b).

In vitro MD extracts were shown to have a strong antiinflammatory effect (induced by lipopolysaccharide) on mice macrophage cell line probably through low-molecular extracted components of the insect (Chu et al., 2013).

Table 11. Immunological status of pigs and rabbits fed insect products. ${ }^{1}$

\begin{tabular}{|c|c|c|c|c|c|c|c|c|}
\hline \multirow[t]{2}{*}{$\begin{array}{l}\text { Animal } \\
\text { [IBW-FBW, kg] } \\
\text { \{no. days }\end{array}$} & \multirow[t]{2}{*}{$\begin{array}{l}\text { Insect } \\
\text { [form] }\end{array}$} & \multicolumn{2}{|c|}{ 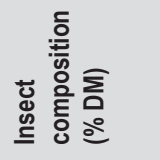 } & \multirow{2}{*}{ 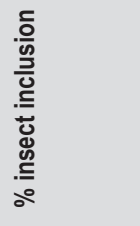 } & \multirow{2}{*}{ 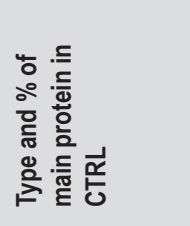 } & \multirow{2}{*}{ 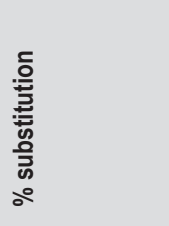 } & \multirow[t]{2}{*}{ Immunological status } & \multirow[t]{2}{*}{ Reference } \\
\hline & & $\mathrm{CP}$ & $\mathrm{CL}$ & & & & & \\
\hline $\begin{array}{l}\text { Piglets } \\
{[1.4-6.7]\{28\}}\end{array}$ & HIL [FF] & 35.9 & 48.1 & 3.5 & $\begin{array}{l}\text { SBM FF: } 12 \% \\
\text { FM: } 11.32 \%\end{array}$ & $\begin{array}{l}\text { SBM FF: } 35 \% \\
\text { FM: } 35 \%\end{array}$ & No effects on haematological parameters & $\begin{array}{l}\text { Driemeyer } \\
(2016)\end{array}$ \\
\hline \multirow[t]{2}{*}{$\begin{array}{l}\text { Weaning pigs } \\
{[6.1 \text {-no data] }\{15\}}\end{array}$} & HIL [FF] & 42.01 & 42.13 & $4 ; 8$ & $\begin{array}{l}\text { Toasted } \\
\text { soybean: } 12\end{array}$ & 50 and $100 \%$ & $\begin{array}{l}\text { No effects on bacterial counts (Lactobacilli } \\
\text { and D-Streptococci) in stomach, proximal }\end{array}$ & $\begin{array}{l}\text { Spranghers } \\
\text { et al. (2018) }\end{array}$ \\
\hline & HIL [DF] & 62.84 & 8.06 & 5.42 & & $72 \%$ & small intestine and distal small intestine. & \\
\hline $\begin{array}{l}\text { Weaning pigs } \\
{[6.1-32.4]\{61\}}\end{array}$ & HIL [DF] & 59.0 & 8.97 & $5 ; 10$ & $\begin{array}{l}\text { SBM: } 20 \% \\
\text { (phase I); } 18.5 \% \\
\text { (phase II) }\end{array}$ & $\begin{array}{l}\text { Phase I: } 30 \\
\text { and } 60 \% ; \\
\text { Phase II: } 32 \\
\text { and } 65 \%\end{array}$ & $\begin{array}{l}\text { Increase in monocytes (linear response) } \\
\text { and neutrophils (quadratic response) }\end{array}$ & $\begin{array}{l}\text { Biasato et al } \\
\text { (2019b) }\end{array}$ \\
\hline $\begin{array}{l}\text { Weaning piglets } \\
{[7.9-17.6]\{28\}}\end{array}$ & HIL [FF] & 37.92 & 38.48 & $1,2,4$ & FM: $4 \%$ & $\begin{array}{l}25,50 \text { and } \\
100 \%\end{array}$ & $\begin{array}{l}\text { Decrease in serum cytokines (IFN- } \mathrm{y} \text { ) } \\
\text { (minimum in pigs fed } 4 \% \mathrm{HIL} \text { ). Increase } \\
\text { in IgA (maximum in pigs fed } 2 \% \mathrm{HIL} \text { ). } \\
\text { Increase in anti-inflammatory cytokine } \\
\mathrm{IL}-10 \text { in pig fed } 2 \% \text { of HIL }\end{array}$ & $\begin{array}{l}\text { Yu et al. } \\
\text { (2020b) }\end{array}$ \\
\hline $\begin{array}{l}\text { Growing pigs } \\
{[18.3-53.2]\{63\}}\end{array}$ & HIL [FF] & 46.6 & - & $\begin{array}{l}9,12,14.5 \\
18.5\end{array}$ & FM: $10 \%$ & $\begin{array}{l}\text { FM: } 25,50,75 \\
\text { and } 100 \%\end{array}$ & Increase in neutrophils & $\begin{array}{l}\text { Chia et al. } \\
(2019)\end{array}$ \\
\hline $\begin{array}{l}\text { Weaning piglets } \\
{[6.9-21.4]\{35\}}\end{array}$ & TMM [FF] & 58.0 & 31.65 & 1,2 & FM: $2 \%$ & 50 and $100 \%$ & $\begin{array}{l}\text { No effect on red blood cells, white blood } \\
\text { cells, lymphocyte, total protein, blood urea } \\
\text { nitrogen, insulin-like growth factor and lgG. }\end{array}$ & $\begin{array}{l}\text { Ao et al. } \\
(2020)\end{array}$ \\
\hline $\begin{array}{l}\text { Weaning pigs } \\
{[8.0 \text {-from } 17.8 \text { to }} \\
20.2]\{35\}\end{array}$ & TMM [FF] & 43.27 & 32.93 & $\begin{array}{l}1.5,3.0 \\
4.5,6.0\end{array}$ & $\begin{array}{l}\text { SMB: } 35.1 \% \\
\text { (phase I); } 27.3 \\
\text { (phase II) }\end{array}$ & $\begin{array}{l}\text { Phase I: } 5,10 \text {, } \\
15 \text { and } 20 \% \text {; } \\
\text { Phase II: } 6 \text {, } \\
\text { 12, } 18,24 \%\end{array}$ & $\begin{array}{l}\text { No effect on } \lg G \text { and } \lg A \text {. Increase in } \\
\text { serum insulin-like growth factor. }\end{array}$ & $\begin{array}{l}\text { Jin et al. } \\
(2016)\end{array}$ \\
\hline
\end{tabular}

${ }^{1} \mathrm{CL}=$ crude lipid; $\mathrm{CP}=$ crude protein; $\mathrm{CTRL}=$ control diet; $\mathrm{DF}=$ defatted; $\mathrm{DM}=$ dry matter; $\mathrm{FBW}=$ final body weight; $\mathrm{FF}=$ full fat; $\mathrm{FM}=$ fishmeal; $\mathrm{HIL}=\mathrm{Hermetia}$ illucens larvae meal; IBW = initial body weight; IgA = immunoglobulin A; IgG = immunoglobulin G; SBM = soybean meal; $\mathrm{TMM}=$ Tenebrio molitor larvae meal. 


\section{Antimicrobial effects and resistance to diseases}

The natural biotope of insects is often infested with hostile microorganisms (Józefiak and Engberg, 2017). To protect themselves, insects produce a wide range of bioactive substances with anti-microbial activity. Thus, HI larvae grown on chicken manure have been shown to reduce the load of Gram negative potential pathogens in the substrate (Józefiak and Engberg, 2017). For example, insects produce many AMPs exhibiting activity against bacteria, fungi, parasites and viruses (Alvarez et al., 2019; Dang et al., 2010; Elhag et al., 2017; Faruk et al., 2016; Imamura et al. 1999; Józefiak and Engberg, 2017; Li et al., 2017b; Moon et al., 1994; Mylonakis et al., 2016; Ohta et al., 2014, 2016; Park et al., 2014, 2015; Ravi et al, 2011; Schuhmann et al. 2003; Vogel et al., 2018; Wu et al. 2018). AMPs' mode of action is usually based on their cationic nature enabling them to form pores in the microbe cell membranes making them natural alternatives to medicinal treatments reducing the risk of developing microbial resistance (Zhang and Gallo, 2016). Moreover, peptides extracted from the larvae of MD and HI were shown to have an anti-tumoral activity (Sun et al., 2014; Tian et al., 2018).

Beside AMPs, FAs may have antimicrobial activities (Suresh et al. 2014). Insects are rich in SCFAs and medium chain FA, such as valeric (5:0), enanthic (7:0), caprylic (8:0), pelargonic (9:0), capric (10:0), myristic (14:0), palmitic (16:0), palmitoleic (16:1), stearic (18:0), oleic (18:1) and linoleic (18:2) which are known to have antifungal and antibacterial activity against both Gram-negative and Gram-positive bacteria (Urbanek et al., 2012). Lauric acid (12:0) in particular has a strong impact on Gram-positive bacteria (Ankaku et al., 2017; Dayrit, 2015).

Chitin and its deacetylated form, chitosan, have also been recognised as having an antimicrobial effect against bacteria, fungi and yeast (Benhabiles et al., 2012; Shin et al. 2019). Their antibacterial activity relies on the interaction between the positively charged chitin/chitosan and the negatively charged microbial cell membranes (Goy et al., 2009). Chitin also has a wound-healing action which could complement its immunostimulating and disease resistance promoting effect (Goy et al., 2009).

The GIT of some carnivorous and omnivorous fish species show enzymatic activity. The chitinases produced by gastric glands and the pancreas are able to hydrolyse the glycosidic bonds of polysaccharides in the chitin of insects and crustaceans (Rangaswamy, 2006; Nogales-Mérida et al., 2019). In general, fish and poultry produce chitinases and present GIT genetically adapted to consume insects, which have been part of their natural diet since ancient times and chitinase activity may increase in animals fed a chitin-rich diet (Nogales-Mérida et al., 2019). Apart from the enzymatic hydrolysis of chitin, chitinase may also be antioxidant and immunostimulant with a potential protective role against bacterial and parasitical infections (Di Rosa et al., 2016; Ngo and Kim, 2014) and such an activity could also partly explain the improved resistance of animals to the bacterial diseases listed below.

\section{Fish and crustaceans}

The rich intestine microbial diversity shown in the first section of this review increases the competition with pathogens for nutrient and colonisation sites in the intestine, and thus may improve resistance to diseases (Cerezuela et al., 2013). Moreover, the modulation of the immune system of fish and crustaceans, as a result of the inclusion of insects in their diets described in the previous section, has been translated in a remarkably improved resistance to bacterial diseases as shown in the few existing studies on dietary TM, MD or SWP listed in Table 8 and 9. To our knowledge, no study has been done so far on the effects of dietary HI on crustaceans or fish resistance to diseases. In Pacific white shrimps, L. vannamei, 10-20\% dietary TM replacing 50$100 \%$ of FM drastically reduced Vibrio parahaemolyticusinduced mortality, from 45 to 13-16\% (Motte et al., 2019). Very low dietary doses of SWP, or silkrose purified from SWP, greatly increased the survival of prawns subjected to an immersion challenge with Vibrio penaecida, from $0 \%$ for control diet-fed prawns to 73-77 and 90-100\% for SWPand silkrose-fed prawns, respectively (Ali et al., 2018). In fish, 5 and $10 \%$ of dietary TM increased the survival of red seabream (Pagrus major) infected with Edwardsiella tarda, from $21 \%$ in the control fish to $55-67 \%$ in the insect-fed fish (Ido et al., 2019). Moreover, 7.5\% of dietary TM improved the resistance of pearl gentian grouper to Vibrio harveyi, but other levels of dietary inclusions either had no effect or even reduced the fish survival rate (Song et al., 2018). The resistance of yellow catfish (Pelteobagrus fulvidraco) to Edwardsiella ictaluri was significantly improved by the addition of $27 \%$ of dietary TM (Su et al., 2017). Dietary MD also improved the survival of swamp eel and black carp (Mylopharyngodon piceus) to Aeromonas hydrophila (Ming et al., 2013; Pei et al., 2019; Xiang et al., 2019) and of red seabream (P. major) to E. tarda (Ido et al., 2015). Because of the similarities between the exoskeletons of insects and parasites, it can be hypothesised that they share some pathogen-associated molecular patterns which may not only improve fish resistance to bacterial diseases as listed before but also resistance to parasitic or even fungal diseases. Although no such study has been undertaken with insect chitin, the closely related crustacean chitin and/or chitosan, have recently been shown to reduce the prevalence and intensity of monogenean in rohu, Labeo rohita (Kumar et al., 2019) and to greatly increased survival of Indian major carp, Cirrhina mrigala, to $75-80 \%$, compared to $10 \%$ in control-fed fish when infected with the aquatic fungus Aphanomyces invadans (Shanthi et al., 2014). These results 
taken together are very positive and suggest that dietary inclusion of insects may represent a healthy supplement for aquafeed of the future.

\section{Poultry}

The immunostimulation of broiler chickens fed 3\% HI discussed in the previous section was translated into an improved survival of chicken when experimentally infected with Salmonella Gallinarum (Lee et al., 2018) (Table 12).

Islam and Yang (2017) showed that $0.4 \%$ of dietary full-fat TM or ZM decreased mortality and increased IgG and IgA levels in broiler chickens challenged with Salmonella and E. coli. The authors speculated that the chitin in TM and ZM larva meal had a probiotic effect that was able to act as a natural antibiotic (Table 12).

\section{Pigs and rabbits}

The antimicrobial effects of HI fat on the microbiota of pigs has been investigated in vitro (Spranghers et al. 2018). The results showed a strong antibacterial effect against Lactobacilli and in particular against D-Streptococci, a Gram-positive bacteria genus that can cause severe damage in the pig industry. The authors did not report any effect against Gram-negative bacteria. The in vitro antibacterial activity of insects fats extracted from both $\mathrm{HI}$ and TM larvae were also investigated in rabbit against common Gram-positive and Gram-negative bacterial pathogenic strains (Salmonella tiphymurium, Salmonella enteritidis, Yersinia enterocolitica, Pasteurella multocida and Listeria monocytogenes) (Dabbou et al., 2020). These bacteria are foodborne pathogens posing public health concern (De Cesare et al. 2017; Kylie et al. 2017; Massacci et al. 2018; Rodriguez-Calleja et al. 2006). The growth of
Y. enterocolitica, L. monocytogenes and P. multocida was impaired by $\mathrm{HI}$ fat, while TM fat only inhibited the growth of P. multocida (Table 13).

In vivo, Ji et al. (2016) suggested a positive effect of AMPs from insects and reported a decrease in the incidence of diarrhoea in weaning piglets fed $5 \%$ of TM, MD or ZM in total substitution of plasma protein meal. However, this effect was not found by Yu et al. (2020b) who fed piglets with up to $4 \%$ of full fat HI meal (Table 13).

\section{Conclusions}

Dietary insects can successfully be used to partially replace conventional protein sources (FM, SBM) without affecting the growth of the animals. However, the lack of large-scale production units (with the exception of housefly) and legislation uncertainties have resulted in high prices and limited amounts of available quantities, both of which currently impair their massive use in animal nutrition. However, the exoskeleton of insects resembles that of parasites, and insects may share pathogen-associated molecular patterns with bacterial or parasitical fish pathogens. They are also rich in short- and medium-chain fatty acids and in chitin, and produce polysaccharides and peptides, all of which may have antimicrobial and/ or immunostimulating activity. The immunostimulation and drastically improved disease resistance highlighted in the present publication (particularly in crustacean and fish studies) suggest that low dietary levels of insects may represent a potent supplement providing 'healthy animal feeds' or 'natural non-specific oral vaccines' to boost the animal immune system. They could be used as a 'preventive cure' before stressful events, such as transport or seasonal temperature changes, which are usually linked to a rise of infection risk.

Table 12. Antimicrobial effects and resistance to diseases induced by insect products in poultry. ${ }^{1}$

\begin{tabular}{|c|c|c|c|c|c|c|}
\hline \multirow{2}{*}{$\begin{array}{l}\text { Poultry species } \\
\text { [IBW-FBW, kg] } \\
\text { \{no. days }\end{array}$} & \multirow[t]{2}{*}{$\begin{array}{l}\text { Insect } \\
\text { [form] }\end{array}$} & \multicolumn{2}{|c|}{$\begin{array}{l}\text { Insect composition } \\
\text { (\% DM) }\end{array}$} & \multirow[t]{2}{*}{$\begin{array}{l}\% \text { insect } \\
\text { inclusion }\end{array}$} & \multirow[t]{2}{*}{ Antimicrobial and diseases resistance } & \multirow[t]{2}{*}{ References } \\
\hline & & $\mathrm{CP}$ & $\mathrm{CL}$ & & & \\
\hline $\begin{array}{l}\text { Broiler chickens } \\
\text { (Ross) } \\
\text { [no data-1,300] }\{30\}\end{array}$ & $\mathrm{HIL}[\mathrm{FF}]$ & - & - & $1,2,3$ & $\begin{array}{l}\text { Reinforced bacterial clearance and increased survival against } \\
\text { Salmonella Gallinarum. Prophylactic properties: Reduced bacterial } \\
\text { burden against S. Gallinarum. Increased survival rate of chicken } \\
\text { experimentally infected with S. Gallinarum in 3\% HIL group. }\end{array}$ & Lee et al. (2018) \\
\hline $\begin{array}{l}\text { Broiler chickens } \\
\text { (Ross 308) } \\
{[39.3-74.8]\{7\}}\end{array}$ & $\begin{array}{l}\text { TMM [FF] } \\
\text { ZMM [FF] }\end{array}$ & $\begin{array}{l}27.26 \\
27.15\end{array}$ & $\begin{array}{l}11.50 \\
8.70\end{array}$ & $0.4 \%$ & $\begin{array}{l}\text { Insect meals were fermented with Lactobacillus plantarum and } \\
\text { Saccharomyces cerevisiae to form probiotics. Increase in survival } \\
\text { rate in birds challenged with Escherichia coli and Salmonella spp. }\end{array}$ & $\begin{array}{l}\text { Islam and Yang } \\
\text { (2017) }\end{array}$ \\
\hline
\end{tabular}


Table 13. Antimicrobial effects and resistance to diseases induced by insect products in pigs and rabbits. ${ }^{1}$

\begin{tabular}{|c|c|c|c|c|c|c|c|c|}
\hline $\begin{array}{l}\text { Animal [IBW-FBW, } \\
\mathrm{kg}] \text { \{no. days }\end{array}$ & \multirow[t]{2}{*}{$\begin{array}{l}\text { Insect } \\
\text { [form] }\end{array}$} & \multicolumn{2}{|c|}{ 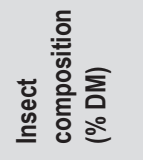 } & \multirow{2}{*}{ 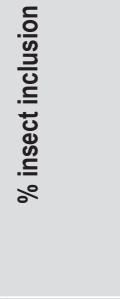 } & \multirow{2}{*}{ 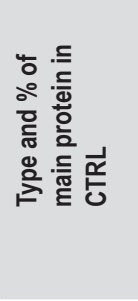 } & \multirow{2}{*}{ 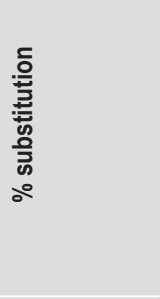 } & \multirow[t]{2}{*}{ Antimicrobial and diseases resistance } & \multirow[t]{2}{*}{ Reference } \\
\hline in vivo trial & & $\mathrm{CP}$ & & & & & & \\
\hline \multirow{3}{*}{$\begin{array}{l}\text { Weaning pigs } \\
{[4.7-\text {-no data] }\{56\}}\end{array}$} & TMM [FF] & 50.2 & 29 & \multirow[t]{3}{*}{5} & Plasma & \multirow[t]{3}{*}{$100 \%$} & \multirow{3}{*}{$\begin{array}{l}\text { Decrease in diarrhoea rate between } 15 \text { and } 28 \\
\text { days of trial }\end{array}$} & \multirow[t]{3}{*}{ Ji et al. (2016) } \\
\hline & $\mathrm{MDL}[\mathrm{FF}]$ & 45.6 & 30.1 & & protein & & & \\
\hline & ZMM [FF] & 45.1 & 41.7 & & $\begin{array}{l}\text { powder: } \\
5 \%\end{array}$ & & & \\
\hline \multicolumn{9}{|l|}{ in vitro trials } \\
\hline $\begin{array}{l}\text { Weaning pigs } \\
{[6.1 \text {-no data] }\{15\}}\end{array}$ & HIF & \multicolumn{5}{|c|}{$\begin{array}{l}\text { Addition of } 0.20,0.50,1.00 \text {, or } 1.50 \mathrm{~g} / 100 \mathrm{~mL} \text { of HIF } \\
\text { (corresponding to } 0.1,0.29,0.58 \text { and } 0.87 \% \mathrm{C} 12: 0 \text { ) } \\
\text { to an incubation medium containing synthetic diet + } \\
\text { phosphate buffer }(\mathrm{pH} 5)+\text { a microbial inoculum from one } \\
\text { donor piglet }\end{array}$} & $\begin{array}{l}0.58 \% \text { had a strong in vitro effect against } \\
\text { D-streptococci }\end{array}$ & $\begin{array}{l}\text { Spranghers et al. } \\
\text { (2018) }\end{array}$ \\
\hline $\begin{array}{l}\text { Rabbits } \\
{[1.05-2.9]\{41\}}\end{array}$ & HIF TMO & & & $0.75,1.5$ & SBO: $1.5 \%$ & 50 and $100 \%$ & $\begin{array}{l}\text { In vitro inhibitory effect of } \mathrm{HIO} \text { against Yersinia } \\
\text { enterocolitica, Pasteurella multocida and } \\
\text { Listeria monocytogenes and of TMO against } P \text {. } \\
\text { multocida }\end{array}$ & $\begin{array}{l}\text { Dabbou et al. } \\
(2020)\end{array}$ \\
\hline
\end{tabular}

Further studies will have to determine for each insect species with a potential for mass production, doses and duration of administration and the range of diseases protection offered to aquatic and terrestrial farmed animals.

\section{Conflict of interest}

The authors declare no conflict of interest.

\section{References}

Ali, M.F.Z., Yasin, I.A., Ohta, T., Hashizume, A., Ido, A., Takahashi, T., Miura, C. and Miura, T., 2018. The silkrose of Bombyx mori effectively prevents vibriosis in penaeid prawns via the activation of innate immunity. Scientific Reports 8. https://doi.org/10.1038/ s41598-018-27241-3

Alvarez, D., Wilkinson, K.A., Treilhou, M., Tene, N., Castillo, D. and Sauvain, M., 2019. Prospecting peptides isolated from black soldier fly (Diptera: Stratiomyidae) with antimicrobial activity against Helicobacter pylori (Campylobacterales: Helicobacteraceae). Journal of Insect Science (Online) 19: 17. https://doi.org/10.1093/jisesa/ iez120

Ankaku, A.A, Akyala, J.I., Juliet, A. and Obianuju, E.C., 2017. Antibacterial activity of lauric acid on some selected clinical isolates. Annals of Clinical and Laboratory Research 5: 2. https:// doi.org/10.21767/2386-5180.1000170
Antonopoulou, E., Nikouli, E., Piccolo, G., Gasco, L., Gai, F., Chatzifotis, S., Mente, E. and Kormas, K.A., 2019. Reshaping gut bacterial communities after dietary Tenebrio molitor larvae meal supplementation in three fish species. Aquaculture 503: 628-635. https://doi.org/10.1016/j.aquaculture.2018.12.013

Ao, X., Yoo, J.S., Wu, Z.L. and Kim, I.H., 2020. Can dried mealworm (Tenebrio molitor) larvae replace fish meal in weaned pigs? Livestock Science 239: 104103. https://doi.org/10.1016/j.livsci.2020.104103. Askarian, F., Zhou, Z., Olsen, R.E., Sperstad, S. and Ringo, E., 2012. Culturable autochthonous gut bacteria in Atlantic salmon (Salmo salar L.) fed diets with or without chitin. Characterization by $16 \mathrm{~S}$ rRNA gene sequencing, ability to produce enzymes and in vitro growth inhibition of four fish pathogens. Aquaculture 326: 1-8. https://doi.org/10.1016/j.aquaculture.2011.10.016

Belforti, M., Gai, F., Lussiana, C., Renna, M., Malfatto, V., Rotolo, L., De Marco, M., Dabbou, S., Schiavone, A., Zoccarato, I. and Gasco, L., 2015.Tenebrio molitor meal in rainbow trout (Oncorhynchus mykiss) diets: effects on animal performance, nutrient digestibility and chemical composition of fillets. Italian Journal of Animal Science14: 670-675. https://doi.org/10.4081/ijas.2015.4170

Belghit, I., Liland, N.S., Gjesdal, P., Biancarosa, I., Menchetti, E., Li, Y., Waagbo, R., Krogdahl, A. and Lock, E.-J., 2019. Black soldier fly larvae meal can replace fish meal in diets of sea-water phase Atlantic salmon (Salmo salar). Aquaculture 503: 609-619. https:// doi.org/10.1016/j.aquaculture.2018.12.032 
Belghit, I., Liland, N.S., Waagbo, R., Biancarosa, I., Pelusio, N., Li, Y., Krogdahl, A. and Lock, E.-J., 2018. Potential of insect-based diets for Atlantic salmon (Salmo salar). Aquaculture 491, 72-81. https:// doi.org/10.1016/j.aquaculture.2018.03.016

Benhabiles, M. S., Salah, R., Lounici, H., Drouiche, N., Goosen, M. F. A. and Mameri, N., 2012. Antibacterial activity of chitin, chitosan and its oligomers prepared from shrimp shell waste. Food Hydrocolloids 29: 48-56. https://doi.org/10.1016/j.foodhyd.2012.02.013

Benzertiha, A., Kierończyk, B., Kołodziejski, P., Pruszyńska-Oszmałek, E., Rawski, M., Józefiak, D. and Józefiak, A., 2020. Tenebrio molitor and Zophobas morio full-fat meals as functional feed additives affect broiler chickens' growth performance and immune system traits. Poultry Science 99: 196-206. https://doi.org/10.3382/PS/PEZ450

Benzertiha, A., Kierończyk, B., Rawski, M., Józefiak, A., Kozłowski, K., Jankowski, J. and Józefiak, D., 2019. Tenebrio molitor and Zophobas morio full-fat meals in broiler chicken diets: effects on nutrients digestibility, digestive enzyme activities, and cecal microbiome. Animals 9: 1128. https://doi.org/10.3390/ani9121128

Biasato, I. Ferrocino, I., Biasibetti, E., Grego, E., Dabbou, S., Sereno, A., Gai, F., Schiavone, A. and Capucchio, M.T., 2018a. Modulation of intestinal microbiota, morphology and mucin composition by dietary insect meal inclusion in free-range chickens. BMC Veterinary Research 14: 383. https://doi.org/10.1186/s12917-018-1690-y

Biasato, I., De Marco, M., Rotolo, L., Renna, M., Lussiana, C., Dabbou, S., Capucchio, M.T., Biasibetti, E., Costa, P., Gai, F., Pozzo, L., Dezzutto, D., Bergagna, S., Martínez, S., Tarantola, M., Gasco, L. and Schiavone, A., 2016. Effects of dietary Tenebrio molitor meal inclusion in free-range chickens. Journal of Animal Physiology and Animal Nutrition 100: 1104-1112. https://doi.org/10.1111/jpn.12487

Biasato, I., Ferrocino, I., Colombino, E., Gai, F., Schiavone, A., Cocolin, L., Capucchio, M.T. and Gasco, L., 2020b. Effects of dietary Hermetia illucens meal inclusion on cecal microbiota and small intestine mucin dynamics and inflammatory status of weaned piglets. Journal of Animal Science and Biotechnology, 11: 64. https://doi. org/10.1186/s40104-020-00466-x

Biasato, I., Ferrocino, I., Dabbou, S., Evangelista, R., Gai, F., Gasco, L., Cocolin, L., Capucchio, M.T. and Schiavone, A., 2020a. Black soldier fly and gut health in broiler chickens: insights into the relationship between cecal microbiota and intestinal mucin composition. Journal of Animal Science and Biotechnology 11: 11. https://doi. org/10.1186/s40104-019-0413-y

Biasato, I., Ferrocino, I., Grego, E., Dabbou, S., Gai, F., Gasco, L., Cocolin,L., Capucchio, M.T. and Schiavone, A., 2019a. Gut Microbiota and Mucin Composition in Female Broiler Chickens Fed Diets including Yellow Mealworm. Animals 9: 213. https://doi. org/10.3390/ani9050213

Biasato, I., Gasco, L., De Marco, M., Renna, M., Rotolo, L., Dabbou, S., Capucchio, M.T., Biasibetti, E., Tarantola, M., Sterpone, L., Cavallarin, L., Gai, F., Pozzo, L., Bergagna, S., Dezzutto, D., Zoccarato, I., Schiavone, A., 2018b. Yellow mealworm larvae (Tenebrio molitor) inclusion in diets for male broiler chickens: effects on growth performance, gut morphology, and histological findings. Poultry Science 97: 540-548. https://doi.org/10.3382/ps/pex308
Biasato, I., Gasco, L., De Marco, M., Renna, M., Rotolo, L., Dabbou, S., Capucchio, M.T., Biasibetti, E., Tarantola, M., Bianchi, C., Cavallarin, L., Gai, F., Pozzo, L., Dezzutto, D., Bergagna, S. and Schiavone, A., 2017. Effects of yellow mealworm larvae (Tenebrio molitor) inclusion in diets for female broiler chickens: implications for animal health and gut histology. Animal Feed Science and Technology 234: 253263. https://doi.org/10.1016/j.anifeedsci.2017.09.014

Biasato, I., Renna, M., Gai, F., Dabbou, S., Meneguz, M., Perona, G., Martinez, S., BarroetaLajusticia, A.C., Bergagna, S., Sardi, L., Capucchio, M.T., Bressan, E., Dama, A., Schiavone, A. and Gasco, L., 2019b. Partially defatted black soldier fly larva meal inclusion in piglet diets: effects on the growth performance, nutrient digestibility, blood profile, gut morphology and histological features. Journal of Animal Science and Biotechnology 10: 12. https://doi.org/10.1186/ s40104-019-0325-x

Borrelli, L., Coretti, L., Dipineto, L., Bovera, F., Menna, F., Chiariotti, L., Nizza, A., Lembo, F. and Fioretti, A., 2017. Insect-based diet, a promising nutritional source, modulates gut microbiota composition and SCFAs production in laying hens. Scientific Reports 7: 16269. https://doi.org/10.1038/s41598-017-16560-6

Bosch, G., van Zanten, H.H.E., Zamprogna, A., Veenenbos, M., Meijer, N.P., van der Fels-Klerx, H.J. and van Loon, J.J.A., 2019. Conversion of organic resources by black soldier fly larvae: Legislation, efficiency and environmental impact. Journal of Cleaner Production 222: 355-363. https://doi.org/10.1016/j.jclepro.2019.02.270

Bovera, F., Loponte, R., Pero, M.E., Cutrignelli, M.I., Calabrò, S., Musco, N., Vassalotti, G., Panettieri, V., Lombardi, P., Piccolo, G., Di Meo, C., Siddi, G., Fliegerova, K. and Moniello, G., 2018. Laying performance, blood profiles, nutrient digestibility and inner organs traits of hens fed an insect meal from Hermetia illucens larvae. Research in Veterinary Science 120: 86-93. https://doi.org/10.1016/j. rvsc.2018.09.006

Bovera, F., Piccolo, G., Gasco, L., Marono, S., Loponte, R., Vassalotti, G., Mastellone, V., Lombardi, P., Attia Y.A and Nizza A. 2015. Yellow mealworm larvae (Tenebrio molitor, L.) as a possible alternative to soybean meal in broiler diets. British Poultry Science 56: 569-575, https://doi.org/10.1080/00071668.2015.1080815

Bradshaw, C.J.A., Leroy, B., Bellard, C., Roiz, D., Albert, C., Fournier, A., Barbet-Massin, M., Salles, J.M., Simard, F. and Courchamp F., 2016. Massive yet grossly underestimated global costs of invasive insects. Nature Communications 7: 12986. https://doi.org/10.1038/ ncomms12986

Bruni, L., Pastorelli, R., Viti, C., Gasco, L. and Parisi, G., 2018. Characterization of the intestinal microbial communities of rainbow trout (Oncorhynchus mykiss) fed with Hermetia illucens (black soldier fly) partially defatted larva meal as partial dietary protein source. Aquaculture 487: 56-63. https://doi.org/10.1016/j. aquaculture.2018.01.006

Caimi, C., Gasco, L., Biasato, I., Malfatto, V., Varello, K., Prearo, M., Pastorino, P., Bona, M.C., Francese, D.R., Schiavone, A., Elia, A.C., Dörr, A.J.M. and Gai, F., 2020. Could Dietary Black Soldier Fly Meal Inclusion Affect the Liver and Intestinal Histological Traits and the Oxidative Stress Biomarkers of Siberian Sturgeon (Acipenser baerii) Juveniles? Animals 10: 155. https://doi.org/10.3390/ani10010155 
Cardinaletti, G., Randazzo, B., Messina, M., Zarantoniello, M., Giorgini, E., Zimbelli, A., Bruni, B., Parisi, G., Olivotto, I. and Tulli, F., 2019. Effects of Graded Dietary Inclusion Level of Full-Fat Hermetia illucens Prepupae Meal in Practical Diets for Rainbow Trout (Oncorhynchus mykiss). Animals 9(5): 251. https://doi.org/10.3390/ ani9050251

Cerezuela, R., Meseguer, J. and Esteban, M.A., 2013. Effects of dietary inulin, Bacillus subtilis and microalgae on intestinal gene expression in gilthead seabream (Sparus aurata L.). Fish \& Shellfish Immunology 34: 843-848. https://doi.org/10.1016/j.fsi.2012.12.026

Chia, S.Y., Tanga, C.M., Osuga, I.M., Alaru, A.O., Mwangi, D.M., Githinji, M., Subramanian, S., Fiaboe, K.K.M., Ekesi, S., van Loon, J.J.A. and Dicke, M., 2019. Effect of dietary replacement of fishmeal by insect meal on growth performance, blood profiles and economics of growing pigs in Kenya. Animals 9: 705. https://doi. org/10.3390/ani9100705

Choi, S.C., Ingale, S.L., Kim, J.S., Park, Y.K., Kwon, I.K. and Chae, B.J., 2013a. An antimicrobial peptide-A3: effects on growth performance, nutrient retention, intestinal and faecal microflora and intestinal morphology of broilers. British Poultry Science 54: 738-746. https:// doi.org/10.1080/00071668.2013.838746

Choi, S.C., Ingale, S.L., Kim, J.S., Park, Y.K., Kwon, I.K. and Chae, B.J., 2013b. Effects of dietary supplementation with an antimicrobial peptide-P5 on growth performance, nutrient retention, excreta and intestinal microflora and intestinal morphology of broilers. Animal Feed Science and Technology 185: 78-84. https://doi.org/10.1016/j. anifeedsci.2013.07.005

Chu, F.J., Jin, X.B., Xu, Y.Y., Ma, Y., Li, X.B., Lu, X.M., Liu, W.B. and Zhu, J.Y., 2013. Inflammatory regulation effect and action mechanism of anti-inflammatory effective parts of housefly (Musca domestica) larvae on atherosclerosis. Evidence-Based Complementary and Alternative Medicine: Article ID 340267: 10 https://doi. org/10.1155/2013/340267

Cutrignelli, M.I., Messina, M., Tulli, F., Randazzo, B., Olivotto, I., Gasco, L., Loponte, R. and Bovera, F., 2018. Evaluation of an insect meal of the Black Soldier Fly (Hermetia illucens) as soybean substitute: Intestinal morphometry, enzymatic and microbial activity in laying hens. Research in Veterinary Science 117: 209-215. https://doi. org/10.1016/j.rvsc.2017.12.020

Dabbou S., Ferrocin, I., Gasco L., Schiavone A., Trocino, A., Xiccato, G., Barroeta A.C., Maione, S., Soglia, D., Biasato, I., Cocolin, L., Gai, F. and Nucera, D.D., 2020. Antimicrobial effects of black soldier fly and yellow mealworm fats and their impact on gut microbiota of growing rabbit. Animals 10: 1292. https://doi.org/10.3390/ani10081292

Dabbou S., Gai F., Biasato I., Capucchio MT., Biasibetti E., Dezzutto D., Meneguz M., Plachà I., Gasco L. and Schiavone A., 2018. Black soldier fly defatted meal as a dietary protein source for broiler chickens: effects on growth performance, blood traits, gut morphology and histological features. Journal of Animal Science and Biotechnology 9: 49. https://doi.org/10.1186/s40104-018-0266-9

Dang, X. L., Wang, Y. S., Huang, Y. D., Yu, X. Q. and Zhang, W. Q., 2010. Purification and characterization of an antimicrobial peptide, insect defensin, from immunized house fly (Diptera: Muscidae), Journal of Medical Entomology 47: 1141-1145. https://doi.org/10.1603/ ME10016
Danieli, P.P., Lussiana, C., Gasco, L., Amici, A. and Ronchi, B., 2019. The effects of diet formulation on the yield, proximate composition, and fatty acid profile of the Black soldier fly (Hermetia illucens L.) prepupae intended for animal feed. Animals 9: 178. https://doi. org/10.3390/ani9040178

Dayrit, F.M., 2015. The properties of lauric acid and their significance in coconut oil. Journal of the American Oil Chemists' Society 92: 1-15. https://doi.org/10.1007/s11746-014-2562-7

De Cesare, A., Parisi, A., Mioni, R., Comin, D., Lucchi, A. and Manfreda, G., 2017. Listeria monocytogenes circulating in rabbit meat products and slaughterhouses in Italy: prevalence data and comparison among typing results. Foodborne Pathogens and Disease 14: 167-176. https://doi.org/10.1089/fpd.2016.2211.

De Souza-Vilela, J., Andrew, N.R. and Ruhnke, I., 2019. Insect protein in animal nutrition. Animal Production Science 59: 2029-2036. https://doi.org/10.1071/AN19255

Di Rosa, M., Distefano, G., Zorena, K. and Malaguarnera, L., 2016. Chitinases and immunity: ancestral molecules with new functions. Immunobiology 221: 399-411. https://doi.org/10.1016/j. imbio.2015.11.014

Driemeyer, H., 2016. Evaluation of black soldier fly (Hermetia illucens) larvae as an alternative protein source in pig creep diets in relation to production, blood and manure microbiology parameters. MSc thesis, University of Stellenbosch, South Africa, p. 114.

Egerton, S., Culloty, S., Whooley, J., Stanton, C. and Ross, R.P., 2018. The gut microbiota of marine fish. Frontiers Microbiology, 9: 873. https://doi.org/10.3389/fmicb.2018.00873.

Elahi, U., Wang, J., Ma, Y.B., Wu, S.G., Wu, J., Qi, G.H. and Zhang, H.J., 2020. Evaluation of yellow mealworm meal as a protein feedstuff in the diet of broiler chicks. Animals 10: 224. https://doi.org/10.3390/ ani10020224

Elhag, O., Zhou, D., Song, Q., Soomro, A.A., Cai, M., Zheng, L., Yu, Z. and Zhang, J., 2017. Screening, expression, purification and functional characterization of novel antimicrobial peptide genes from Hermetia illucens (L.). PLoS ONE 12: e0169582. https://doi. org/10.1371/journal.pone.0169582

Elia, A.C., Capucchio, M.T., Caldaroni, B., Magara, G., Dorr, A.J.M., Biasato, I., Biasibetti, E., Righetti, M., Pastorino, P., Prearo, M., Gai, F., Schiavone, A. and Gasco, L., 2018. Influence of Hermetia illucens meal dietary inclusion on the histological traits, gut mucin composition and the oxidative stress biomarkers in rainbow trout (Oncorhynchus mykiss). Aquaculture 496: 50-57. https://doi. org/10.1016/j.aquaculture.2018.07.009

Esteban, M.A., Cuesta, A., Ortuño, J. and Meseguer, J., 2001. Immunomodulatory effects of dietary intake of chitin on gilthead seabream (Sparus aurata L.) innate immune system. Fish \& Shellfish Immunology 11: 303-315. https://doi.org/10.1006/fsim.2000.0315

Food and Agriculture Organization of the United Nations (FAO), 2020. Forecasting threats to the food chain affecting food security in countries and regions. Food Chain Crisis Early Warning Bulletin no. 34, January-March 2020. FAO, Rome, Italy. Available at http:// www.fao.org/publications/card/en/c/ca7582en/.

Faruk, M.O., Yusof, F and Chowdhury, S., 2016. An overview of antifungal peptides derived from insect. Peptides 80: 80-88. https:// doi.org/10.1016/j.peptides.2015.06.001 
Foysal, M.J., Fotedar, R., Tay, C. and Gupta, S.K., 2019. Dietary supplementation of black soldier fly (Hermetica illucens) meal modulates gut microbiota, innate immune response and health status of marron (Cherax cainii, Austin 2002) fed poultry-byproduct and fishmeal based diets. Peer) 7. https://doi.org/10.7717/ peerj.6891

Gariglio, M., Dabbou, S., Crispo, M., Biasato, I., Gai, F., Gasco, L., Piacente, F., Odetti, P., Bergagna, S., Plachà, I., Valle, E., Colombino, E., Capucchio, M.T. and Schiavone, A., 2019. Effects of the dietary inclusion of partially defatted black soldier fly (Hermetia illucens) meal on the blood chemistry and tissue (spleen, liver, thymus, and bursa of Fabricius) histology of muscovy ducks (Cairina moschata domestica). Animals 9: 307. https://doi.org/10.3390/ani9060307

Gasco, L., Acuti, G., Bani, P., Dalle Zotte, A., Danieli, P.P., De Angelis, A., Fortina, R., Marino, R., Parisi, G., Piccolo, G., Pinotti, L., Prandini, A., Schiavone, A., Terova, G., Tulli, F. and Roncarati, A., 2020a. Insects and fish by-products as sustainable alternatives to conventional animal proteins in animal nutrition. Italian Journal of Animal Science 19: 360-372. https://doi.org/10.1080/182805 1X.2020.1743209

Gasco, L., Biancarosa, I. and Liland, N.S., 2020b. From waste to feed: a review of recent knowledge on insects as producers of protein and fat for animal feeds. Current Opinion in Green and Sustainable Chemistry 23: 67-79. https://doi.org/10.1016/j.cogsc.2020.03.003

Gasco, L., Biasato, I., Dabbou, S., Schiavone, A. and Gai, F., 2019a. Animals fed insect-based diets: state-of-the-art on digestibility, performance and product quality. Animals 9: 170. https://doi. org/10.3390/ani9040170.

Gasco, L., Dabbou, S., Trocino, A., Xiccato, G., Capucchio, M.T., Biasato, I., Dezzutto, D., Birolo, M., Meneguz, M., Schiavone, A. and Gai, F., 2019b. Effect of dietary supplementation with insect fats on growth performance, digestive efficiency and health of rabbits. Journal of Animal Science and Biotechnology 10: 4. https://doi. org/10.1186/s40104-018-0309-2

Gasco, L., Finke, M. and Van Huis, A., 2018b. Can diets containing insects promote animal health? Journal of Insects as Food and Feed 4: 1-4. https://doi.org/10.3920/jiff2018.x001

Gasco, L., Gai, F., Maricchiolo, G., Genovese, L., Ragonese, S., Bottari, T. and Caruso, G., 2018a. Fish meal alternative protein sources for aquaculture feeds. In: Gasco, L., Gai, F., Maricchiolo, G., Genovese, L., Ragonese, S., Bottari, T., Caruso, G. (eds) Feeds for the aquaculture sector - current situation and alternative sources. Springer Briefs in Molecular Science. Lightning Source UK Ltd, Cham, Switzerland, pp. 1-28. https://doi.org/10.1007/978-3-31977941-6

Gasco, L., Henry, M., Piccolo, G., Marono, S., Gai, F., Renna, M., Lussiana, C., Antonopoulou, E., Mola, P. and Chatzifotis, S., 2016. Tenebrio molitor meal in diets for European sea bass (Dicentrarchus labrax L.)juveniles: growth performance, whole body composition and in vivo apparent digestibility. Animal Feed Science and Technology 220: 34-45. https://doi.org/10.1016/j. anifeedsci.2016.07.003

Goulson, D., 2019. The insect apocalypse and why it matters. Current Biology 29: R942-R995. https://doi.org/10.1016/j.cub.2019.06.069
Goy, R.C., Debritto, D. and Assis, O.B.G., 2009. A review of the antimicrobial activity of chitosan. Polímeros 19: 241-247. https:// doi.org/10.1590/S0104-14282009000300013

Guerrerio, I. Oliva-Teles, A. and Enes, P., 2018. Prebiotics as functional ingredients: focus on Mediterranean fish aquaculture. Reviews in Aquaculture 10: 800-832. https://doi.org/10.1111/raq.12201

Hardy, K., Radini, A., Buckley, S., Blasco, R., Copeland, L., Burjachs, F., Girbal, J., Yll, R., Carbonell, E. and Bermúdez de Castro, J.M., 2016. Diet and environment 1.2 million years ago revealed through analysis of dental calculus from Europe's oldest hominin at Simadel Elefante, Spain. The Science of Nature 104: 2. https://doi.org/10.1007/s00114016-1420-x

Henry, M., Gasco, L., Piccolo, G. and Fountoulaki, E., 2015. Review on the use of insects in the diet of farmed fish: Past and future. Animal Feed Science and Technology 203: 1-22. https://doi.org/10.1016/j. anifeedsci.2015.03.001

Henry, M.A., Gai, F., Enes, P., Perez-Jimenez, A. and Gasco, L., 2018b. Effect of partial dietary replacement of fishmeal by yellow mealworm (Tenebrio molitor) larvae meal on the innate immune response and intestinal antioxidant enzymes of rainbow trout (Oncorhynchus mykiss). Fish \& Shellfish Immunology 83: 308-313.

Henry, M.A., Gasco, L., Chatzifotis, S. and Piccolo, G., 2018a. Does dietary insect meal affect the fish immune system? The case of mealworm, Tenebrio molitor on European sea bass, Dicentrarchus labrax. Developmental \& Comparative Immunology 81: 204-209. https://doi.org/10.1016/j.dci.2017.12.002

Huyben, D., Vidakovic, A., Werner Hallgren, S. and Langeland, M., 2019. High-throughput sequencing of gut microbiota in rainbow trout (Oncorhynchus mykiss) fed larval and pre-pupae stages of black soldier fly (Hermetia illucens). Aquaculture 500: 485-491. https://doi.org/10.1016/j.aquaculture.2018.10.034

Ido, A., Hashizume, A., Ohta, T., Takahashi, T., Miura, C. and Miura, T., 2019. Replacement of fish meal by defatted yellow mealworm (Tenebrio molitor) larvae in diet improves growth performance and disease resistance in red seabream (Pagrus major). Animals 9: 100. https://doi.org/10.3390/ani9030100

Ido, A., Iwai, T., Ito, K., Ohta, T., Mizushige, T., Kishida, T., Miura, C. and Miura, T., 2015. Dietary effects of housefly (Musca domestica) (Diptera: Muscidae) pupae on the growth performance and the resistance against bacterial pathogen in red sea bream (Pagrus major) (Perciformes: Sparidae). Applied Entomology and Zoology 50: 213-221. https://doi.org/10.1007/s13355-015-0325-z

Imamura, M., Wada, S., Koizumi, N., Kadotani, T., Yaoi, K., Sato, R. and Iwahana, H., 1999. Acaloleptins A: inducible antibacterial peptides from larvae of the beetle, Acalolepta luxuriosa. Archives of Insect Biochemistry and Physiology 40: 88-98. https://doi.org/10.1002/ (SICI)1520-6327(1999)40:2<88::AID-ARCH3>3.0.CO;2-B

Islam, M.M. and Yang, C.-J., 2017. Efficacy of mealworm and super mealworm larvae probiotics as an alternative to antibiotics challenged orally with Salmonella and E. coli infection in broiler chicks. Poultry Science 96: 27-34. https://doi.org/10.3382/ps/pew220 Ji, Y.J., Liu, H. N., Kong, X. F., Blachier, F., Geng, M.M., Liu, Y. Y. and Yin Y. L., 2016. Use of insect powder as a source of dietary protein in early-weaned piglets. Journal Animal Science 94: 111-116. https:// doi.org/10.2527/jas2015-9555 
Jin, X.H., Heo, P.S., Hong, J.S., Kim, N.J. and Kim, Y.Y., 2016. Supplementation of dried mealworm (Tenebrio molitor larva) on growth performance, nutrient digestibility and blood profiles in weaning pigs. Asian-Australasian Journal Animal Science 29: 97986. https://doi.org/10.5713/ajas.15.0535

Józefiak, A. and Engberg, R.M., 2017. Insect proteins as a potential source of antimicrobial peptides in livestock production. A review. Journal of Animal and Feed Sciences 26: 87-99. https:// doi.org/10.22358/jafs/69998/2017

Józefiak, A., Benzertiha, A., Kierończyk, B., Łukomska, A., Wesołowska, I. and Rawski, M., 2020. Improvement of cecal commensal microbiome following the insect additive into chicken diet. Animals 10: 577. https://doi.org/10.3390/ani10040577

Józefiak, A., Kierończyk, B., Rawski, M., Mazurkiewicz, J., Benzertiha, A., Gobbi, P., Nogales-Mérida, S., Świątkiewicz, S. and Józefiak, D., 2018. Full-fat insect meals as feed additive - the effect on broiler chicken growth performance and gastrointestinal tract microbiota. Journal of Animal and Feed Sciences 2: 131-139. https:// doi.org/10.22358/jafs/91967/2018

Józefiak, A., Nogales-Merida, S., Mikołajczak, Z. and Mazurkiewicz, J., 2019b. The utilization of full-fat insect meal in rainbow trout (Oncorhynchus mykiss) nutrition: The effects on growth performance, intestinal microbiota and gastro-intestinal tract histomorphology. Annals of Animal Science 19: 747-765. https:// doi.org/10.2478/aoas-2019-0020

Józefiak, A., Nogales-Merida, S., Rawski, M., Kieronczyk, B. and Mazurkiewicz, J., 2019a. Effects of insect diets on the gastrointestinal tract health and growth performance of Siberian sturgeon (Acipenser baerii Brandt, 1869). BMC Veterinary Research 15: 348. https://doi. org/10.1186/s12917-019-2070-y

Józefiak, D., Józefiak, A., Kierończyk, B., Rawski, M., Świątkiewicz, S., Długosz, J. and Engberg, R.M., 2016. Insects - a natural nutrient source for poultry - a review. Annals of Animal Science 16. https:// doi.org/10.1515/aoas-2016-0010

Kaiser, P. and Balic, A., 2015. The avian immune system. Chapter 17. In: Scanes, C.G (ed.) Sturkie's avian physiology ( $6^{\text {th }}$ Ed.). Academic Press, San Diego, CA, USA, pp. 403-418. https://doi.org/10.1016/ B978-0-12-407160-5.00017-8

Kayama, H., Okumura, R. and Takeda, K., 2020. Interaction between the microbiota, epithelia, and immune cells in the intestine. Annual Review of Immunology 38: 23-48. https://doi.org/10.1146/annurevimmunol-070119-115104

Khan, S.H., 2018. Recent advances in role of insects as alternative protein source in poultry nutrition. Journal of Applied Animal Research 46: 1144-1157. https://doi.org/10.1080/09712119.2018 .1474743

Kierończyk, B., Rawski, M., Józefiak, A., Mazurkiewicz, J., Świątkiewicz, S., Siwek, M., Bednarczyk, M., Szumacher-Strabel, M., Cieślak, A., Benzertiha, A. and Józefiak, D. 2018. Effects of replacing soybean oil with selected insect fats on broiler. Animal Feed Science and Technology 240: 170-183. https://doi.org/10.1016/j. anifeedsci.2018.04.002

Klasing, K.C., 2005. Poultry Nutrition: A Comparative Approach. Journal of Applied Poultry Research 14: 426-436. https://doi. org/10.1093/japr/14.2.426
Kouřimská, L. and Adámková A., 2016. Nutritional and sensory quality of edible insects. NFS Journal 4: 22-26. https://doi.org/10.1016/j. nfs.2016.07.001

Koutsos, L., McComb A. and Finke, M., 2019. Insect composition and uses in animal feeding applications: A brief review. Annals of the Entomological Society of America 112: 544-551. https://doi. org/10.1093/aesa/saz033

Kumar, R., Kaur, N. and Kamilya, D., 2019. Chitin modulates immunity and resistance of Labeo rohita (Hamilton, 1822) against gill monogeneans. Aquaculture 498: 522-527. https://doi.org/10.1016/j. aquaculture.2018.09.013

Kylie, K., McEwen, S.A., Boerlin, P., Reid-Smith, M.J., Weese, J.S. and Turner, P.V., 2017. Prevalence of antimicrobial resistance in fecal Escherichia coli and Salmonella enterica in Canadian commercial meat, companion, laboratory, and shelter rabbits (Oryctolagus cuniculus) and its association with routine antimicrobial use in commercial meat rabbits. Preventive Veterinary Medicine 147: 53-57. https://doi.org/10.1016/j.prevetmed.2017.09.004.

Lee, C.G., Da Silva, C.A., Lee, J.Y., Hartl, D. and Elias, J.A., 2008. Chitin regulation of immune responses: an old molecule with new roles. Current Opinion in Immunology 20: 684-691. https://doi. org/10.1016/j.coi.2008.10.002

Lee, J., Kim, Y-M., Park, Y-K., Yang, Y-C., Jung, B-G. and Lee B-J., 2018. Black soldier fly (Hermetia illucens) larvae enhances immune activities and increases survivability of broiler chicks against experimental infection of Salmonella Gallinarum. Journal of Veterinaly Medical Science 80: 736-740. https://doi.org/10.1292/ jvms.17-0236

Li, S., Ji, H., Zhang, B., Zhou, J. and Yu, H., 2017a. Defatted black soldier fly (Hermetia illucens) larvae meal in diets for juvenile Jian carp (Cyprinus carpio var. Jian): Growth performance, antioxidant enzyme activities, digestive enzyme activities, intestine and hepatopancreas histological structure. Aquaculture and Fisheries Management 477: 62-70. https://doi.org/10.1016/j.aquaculture.2017.04.015

Li, Y., Kortner, T.M., Chikwati, E.M., Belghit, I., Lock, E.-J. and Krogdahl, A., 2020. Total replacement of fish meal with black soldier fly (Hermetia illucens) larvae meal does not compromise the gut health of Atlantic salmon (Salmo salar). Aquaculture 520: 734967. https://doi.org/10.1016/j.aquaculture.2020.734967

Li, Y., Kortner, T.M., Chikwati, E.M., Munang'andu, H.M., Lock, E.-J. and Krogdahl, A., 2019. Gut health and vaccination response in presmolt Atlantic salmon (Salmo salar) fed black soldier fly (Hermetia illucens) larvae meal. Fish \& Shellfish Immunology 86: 1106-1113. https://doi.org/10.1016/j.fsi.2018.12.057

Li, Z., Mao, R., Teng, D. Hao, Y., Chen, H., Wang, X., Wang, X, Yang, N and Wang, J. 2017b. Antibacterial and immunomodulatory activities of insect defensins-DLP2 and DLP4 against multidrug-resistant Staphylococcus aureus. Scientific Reports, 7: 12124. https://doi. org/10.1038/s41598-017-10839-4

Liland, N.S., Biancarosa, I., Araujo, P., Biemans, D., Bruckner, C.G., Waagbø, R., Torstensen, B.E. and Lock, E-J., 2017. Modulation of nutrient composition of black soldier fly (Hermetia illucens) larvae by feeding seaweed-enriched media. PLoS ONE 12:e0183188. https://doi.org/10.1371/journal.pone.0183188 
Lock, E.R., Arsiwalla, T. and Waagbo, R., 2016. Insect larvae meal as an alternative source of nutrients in the diet of Atlantic salmon (Salmo salar) postsmolt. Aquaculture Nutrition 22: 1202-1213. https://doi.org/10.1111/anu.12343

Lock, E-J., Biancarosa, I. and Gasco, L., 2018. Insects as raw materials in compound feed for aquaculture. In: Halloran, A., Flore, R., Vantomme, P., Roos, N. (eds) Edible insects in sustainable food systems. Springer, Cham, Switzerland, pp 263-276. https://doi. org/10.1007/978-3-319-74011-9_16

Magalhaes, R., Sanchez-Lopez, A., Leal, R.S., Martinez-Llorens, S., Oliva-Teles, A. and Peres, H., 2017. Black soldier fly (Hermetia illucens) pre-pupae meal as a fish meal replacement in diets for European seabass (Dicentrarchus labrax). Aquaculture 476: 79-85. https://doi.org/10.1016/j.aquaculture.2017.04.021

Marono, S., Loponte, R., Lombardi, P., Vassalotti, G., Pero, M.E., Russo, F., Gasco, L., Parisi, G., Piccolo, G., Nizza, S., Di Meo, C., Attia, Y.A. and Bovera, F., 2017. Productive performance and blood profiles of laying hens fed Hermetia illucens larvae meal as total replacement of soybean meal from 24 to 45 weeks of age. Poultry Science 96, 1783-1790. https://doi.org/10.3382/ps/pew461

Massacci, F.R., Magistrali, C.F., Cucco, L., Curcio, L., Bano, L., Mangili, P., Scoccia, E.,Bisgaard, M., Aalbæk, B. and Christensen, H., 2018. Characterization of Pasteurella multocida involved in rabbit infections. Veterinary Microbiology 213: 66-72. https://doi. org/10.1016/j.vetmic.2017.11.023

Mbhele, F.G.T., Mnisi, C.M. and Mlambo, V.A., 2019. Nutritional evaluation of insect meal as a sustainable protein source for jumbo quails: physiological and meat quality responses. Sustainability 11: 6592. https://doi.org/10.3390/su11236592

McCarville, J.L., Chen, G.Y., Cuevas, V.D., Troha, K. and Ayres, J.S., 2020. Microbiota Metabolites in Health and Disease. Annual Review of Immunology 38: 147-170. https://doi.org/10.1146/annurevimmunol-071219-125715

Mikołajczak, Z., Rawski, M., Mazurkiewicz, J., Kierończyk, B. and Józefiak, D., 2020. The effect of hydrolyzed insect meals in sea trout fingerling (Salmo trutta) diets on growth performance, microbiota and biochemical blood parameters. Animals 10: 1031. https://doi. org/10.3390/ani10061031

Ming, J., Ye, J., Zhang, Y., Yang, X., Wu, C., Shao, X. and Liu, P., 2013. The influence of maggot meal and l-carnitine on growth, immunity, antioxidant indices and disease resistance of black carp (Mylopharyngodon piceus). Journal of the Chinese Cereals and Oils Association 28: 80-86

Moniello, G., Ariano, A., Panettieri, V., Tulli, F., Olivotto, I., Messina, M., Randazzo, B., Severino, L., Piccolo, G., Musco, N., Addeo, N.F., Hassoun, G. and Bovera, F., 2019. Intestinal Morphometry, Enzymatic and Microbial Activity in Laying Hens Fed Different Levels of a Hermetia illucens Larvae Meal and Toxic Elements Content of the Insect Meal and Diets. Animals 9: 86. https://doi. org/10.3390/ani9030086

Moon, H.J., Lee, S.Y., Kurata, S., Natori, S. and Lee, B.L., 1994. Purification and molecular cloning of cDNA for an inducible antibacterial protein from larvae of the coleopteran, Tenebrio molitor. Journal of Biochemistry 116: 53-58. https://doi.org/10.1093/ oxfordjournals.jbchem.a124502
Mortensen, F.V., Langkilde, N.C., Joergensen, J.C. and Hessov, I., 1999. Short-chain fatty acids stimulate mucosal cell proliferation in the closed human rectum after Hartmann's procedure. International Journal of Colorectal Disease 14: 150-154. https://doi.org/10.1007/ s003840050201

Motte, C., Rios, A., Lefebvre, T., Do, H., Henry, M. and Jintasataporn, O., 2019. Replacing fish meal with defatted insect meal (yellow mealworm Tenebrio molitor) improves the growth and immunity of pacific white shrimp (Litopenaeus vannamei). Animals 9: 258. https://doi.org/10.3390/ani9050258

Mylonakis, E., Podsiadlowski, L., Muhammed, M. and Vilcinskas, A., 2016. Diversity, evolution and medical application of insect antimicrobial peptides. Philosophical Transactions of the Royal Society B 371: 20150290. https://doi.org/10.1098/rstb.2015.0290

Ngo, D-H. and Kim, S-E., 2014. Antioxidant effects of chitin, chitosan, and their derivatives. Advances in Food and Nutrition Research 73: 15-31. https://doi.org/10.1016/B978-0-12-800268-1.00002-0

Nogales-Mérida, S., Gobbi, P., Józefiak, D., Mazurkiewicz, J., Dudek, K., Rawski, M., Kierończyk, B. and Józefiak, A., 2019. Insect meals in fish nutrition. Reviews in Aquaculture 11: 1080-1103. https:// doi.org/10.1111/raq.12281

Noriega, J.A., Hortal, J.,Azcárate, F.M., Berg, M.,Bonada, N., Briones, M.J., Del Toro, I., Goulson, D., Ibañez, S., Landis, D.A., Moretti, M., Pott, S.G., Slade, E.M., Stout, J.C., Ulyshen, M.D., Wackers, F.L., Woodcock, B.A and Santos, A.M.C., 2018. Research trends in ecosystem services provided by insects. Basic and Applied Ecology 26: 8-23. https://doi.org/10.1016/j.baae.2017.09.006

Ohta, T., Ido, A., Kusano, K., Miura, C. and Miura, T., 2014. A Novel Polysaccharide in Insects Activates the Innate Immune System in Mouse Macrophage RAW264 Cells. PLoS ONE 9: e114823. https:// doi.org/10.1371/journal.pone.0114823

Ohta, T., Kusano, K., Ido, A., Miura, C. and Miura, T., 2016. Silkrose: A novel acidic polysaccharide from the silkmoth that can stimulate the innate immune response. Carbohydrate Polymers 136: 995-1001. https://doi.org/10.1016/j.carbpol.2015.09.070

Oonincx, D.G.A.B., Van Broekhoven, S.V., Van Huis, A. and Van Loon, J.J.A., 2015. Feed conversion, survival and development, and composition of four insect species on diets composed of food by-products. PLoS ONE, 10: e0144601. https://doi.org/10.1371/ journal.pone. 0144601

Ostaszewska, T., Dabrowski, K., Kwasek, K., Verri, T., Kamaszewski, M., Sliwinski, J. and Napora-Rutkowski, L., 2011. Effects of various diet formulations (experimental and commercial) on the morphology of the liver and intestine of rainbow trout (Oncorhynchus mykiss) juveniles. Aquaculture Research 42: 1796-1806. https://doi. org/10.1111/j.1365-2109.2010.02779.x

Paini, D.R. Sheppard, A.W., Cook, D.C., De Barro, P.J., Worner, S.P and Thomas, M.B., 2016. Global threat to agriculture from invasive species. Proceedings of the National Academy of Sciences of the United States of America 113: 7575-7579. https://doi.org/10.1073/ pnas.1602205113

Park S.I., Kim, J-W. and Yoe, S.M., 2015. Purification and characterization of novel antibacterial peptide from black soldier fly (Hermetia illucens) larvae. Developmental and Comparative Immunology 52: 98-106. https://doi.org/10.1016/j.dci.2015.04.018 
Park, S.I., Chang, B.S. and Yoe. S.M., 2014. Detection of antimicrobial substances from larvae of the black soldier fly, Hermetia illucens (Diptera: Stratiomyidae). Entomological Research. 44: 58-64. https:// doi.org/10.1111/1748-5967.12050

Pei, M.T., Yang, C., Yang, D.Q. and Yi, T.L., 2019. Effects of housefly maggot meal and earthworms on growth and immunity of the Asian swamp eel Monopterus albus (Zuiew). The Israeli Journal of Aquaculture - Bamidgeh 71: 8. http://hdl.handle.net/10524/62904 Qin, C., Zhang, Y., Liu, W., Xu, L., Yang, Y. and Zhou, Z., 2014. Effects of chito-oligosaccharides supplementation on growth performance, intestinal cytokine expression, autochthonous gut bacteria and disease resistance in hybrid tilapia Oreochromis niloticus $+\mathrm{x}$ Oreochromis aureus $\hat{\partial}$. Fish \& Shellfish Immunololy 40: 267-274. https://doi.org/10.1016/j.fsi.2014.07.010

Rangaswamy, C.P., 2006. Physiology of digestion in fish and shrimp. In: Ali SA (ed.) Training manual on shrimp and fish nutrition and feed management. Central Institute of Brackish Water Aquaculture, Chennai, India, pp. 2-9.

Ravi, C., Jeyashree, A. and Renuka Devi, K., 2011. Antimicrobial peptides from insects: an overview. Research in Biotechnology 2: 1-7.

Rimoldi S., Gini, E., Iannini, F., Gasco, L.and Terova, G., 2019. The effects of dietary insect meal from Hermetia illucens prepupae on autochthonous gut microbiota of rainbow trout (Oncorhynchus mykiss). Animals 9: 143 https://doi.org/10.3390/ani9040143

Ringø, E., Zhou, Z., Olsen, R.E. and Song, S.K., 2012. Use of chitin and krill in aquaculture - the effect on gut microbiota and the immune system: a review. Aquaculture Nutrition 18: 117-131. https://doi. org/10.1111/j.1365-2095.2011.00919.x

Rodriguez-Calleja, J.M., Garcia-Lopez, I., Garcia Lopez, M.L., Santos, J.A. and Otero, A., 2006. Rabbit meats as a source of bacterial foodborne pathogens. Journal of Food Protection 69: 1106-1112. https://doi.org/10.4315/0362-028x-69.5.1106

Sankian, Z., Khosravi, S., Kim, Y.O. and Lee, S.M., 2018. Effects of dietary inclusion of yellow mealworm (Tenebrio molitor) meal on growth performance, feed utilization, body composition, plasma biochemical indices, selected immune parameters and antioxidant enzyme activities of mandarin fish (Siniperca scherzeri) juveniles. Aquaculture 496: 79-87. https://doi.org/10.1016/j. aquaculture.2018.07.012

Schiavone, A., Dabbou, S., De Marco, M., Cullere, M., Biasato, I., Biasibetti, E., Capucchio, M.T., Bergagna, S., Dezzutto, D., Meneguz, M., Gai, F., Dalle Zotte A. and Gasco, L., 2018. Black soldier fly larva fat inclusion in finisher broiler chicken diet as an alternative fat source. Animal 12: 2032-2039. https://doi.org/10.1017/ S1751731117003743.

Schiavone, A., Dabbou, S., Petracci, M., Zampiga, M., Sirri, F., Biasato, I., Gai, F. and Gasco, L. 2019. Black soldier fly defatted meal as a dietary protein source for broiler chickens: Effects on carcass traits, breast meat quality and safety. Animal 13: 2397-2405. https://doi. org/10.1017/S1751731119000685

Schuhmann, B., Seitz, V., Vilcinskas, A. and Podsiadlowski, L., 2003. Cloning and expression of gallerimycin, an antifungal peptide expressed in immune response of greater wax moth larvae, Galleria mellonella. Archives of Insect Biochemistry and Physiology 53: 125-133. https://doi.org/10.1002/arch.10091
Shanthi Mari, L.S., Jagruthi, C., Anbazahan, S.M., Yogeshwari, G., Thirumurugan, R., Arockiaraj, J., Mariappan, P., Balasundaram, C. and Harikrishnan, R., 2014. Protective effect of chitin and chitosan enriched diets on immunity and disease resistance in Cirrhina mrigala against Aphanomyces invadans. Fish \& Shellfish Immunology 39: 378-385. https://doi.org/10.1016/j.fsi.2014.05.027

Shin, C.-S., Kim, D.-Y. and Shin, W.-S., 2019. Characterization of chitosan extracted from mealworm beetle (Tenebrio molitor, Zophobasmorio) and rhinoceros beetle (Allomyrina dichotoma) and their antibacterial activities. International Journal of Biological Macromolecules 125: 72-77. https://doi.org/10.1016/j. ijbiomac.2018.11.242

Smetana, S., Schmitt, E. and Mathys, A., 2019. Sustainable use of Hermetia illucens insect biomass for feed and food: Attributional and consequential life cycle assessment. Resources, Conservation and Recycling 144: 285-296. https://doi.org/10.1016/j. resconrec.2019.01.042

Sogari, G., Amato, M., Biasato, I., Chiesa, S. and Gasco, L. 2019. The potential role of insects as feed: a multi-perspective review. Animals 9: 119. https://doi.org/10.3390/ani9040119

Song, S.G., Chi, S.Y., Tan, B.P., Liang, G.L., Lu, B.Q., Dong, X.H., Yang, Q.H., Liu, H.Y. and Zhang, S., 2018. Effects of fishmeal replacement by Tenebrio molitor meal on growth performance, antioxidant enzyme activities and disease resistance of the juvenile pearl gentian grouper (Epinephelus lanceolatus male x Epinephelus fuscoguttatus female). Aquaculture Research 49: 2210-2217. https:// doi.org/10.1111/are.13677

Spranghers, T., Joris, M., Vrancx, J., Ovyn, A., Eeckhout, M., De Clercq, P. and De Smet, S., 2018. Gut antimicrobial effects and nutritional value of black soldier fly (Hermetia illucens L.) prepupae for weaned piglets. Animal Feed Science and Technology 235: 33-42. https:// doi.org/10.1016/j.anifeedsci.2017.08.012

Stenberg, O.K., Holen, E., Piemontese, L., Liland, N.S., Lock, E.-J., Espe, M. and Belghit, I., 2019. Effect of dietary replacement of fish meal with insect meal on in vitro bacterial and viral induced gene response in Atlantic salmon (Salmo salar) head kidney leukocytes. Fish \& Shellfish Immunology 91: 223-232. https://doi.org/10.1016/j. fsi.2019.05.042

St-Hilaire, S., Cranfill, K., McGuire, M.A., Mosley, E.E., Tomberlin, J.K., Newton, L., Sealey, W., Sheppard, C., Irving, S., 2007. Fish offal recycling by the black soldier fly produces a foodstuff high in omega-3 fatty acids. Journal of the World Aquaculture Society 38: 309-313.

Su, J., Gong, Y., Cao, S., Lu, F., Han, D., Liu, H., Jin, J., Yang, Y., Zhu, X. and Xie, S., 2017. Effects of dietary Tenebrio molitor meal on the growth performance, immune response and disease resistance of yellow catfish (Pelteobagrus fulvidraco). Fish \& Shellfish Immunology 69: 59-66. https://doi.org/10.1016/j.fsi.2017.08.008

Sun, H-X., Chen, L-Q., Zhang, J. and Chen, F-Y., 2014. Anti-tumor and immunomodulatory activity of peptide fraction from Musca domestica. Journal of Ethnopharmacology 153: 831-839. https:// doi.org/10.1016/j.jep.2014.03.052 
Suresh, A., Praveenkumar, R., Thangaraj, R., Oscar, F.L., Baldev, E., Dhanasekaran, D. and Thajuddin, N., 2014. Microalgal fatty acid methyl ester a new source of bioactive compounds with antimicrobial activity. Asian Pacific Journal of Tropical Disease 4, Suppl. 2: S979-S984. https://doi.org/10.1016/S2222-1808(14)60769-6

Sypniewski, J., Kierończyk, B., Benzertiha, A., Mikołajczak, Z., Pruszyńska-Oszmałek, E., Kołodziejski, P., Sassek, M., Rawski, M., Czekała, W. and Józefiak, D., 2020. Replacement of soybean oil by Hermetia illucens fat in turkey nutrition: effect on performance, digestibility, microbial community, immune and physiological status and final product quality. British Poultry Science 61: 294-302. https://doi.org/10.1080/00071668.2020.1716302

Terova, G., Rimoldi, S., Ascione, C., Gini, E., Ceccotti, C. and Gasco, L., 2019. Rainbow trout (Oncorhynchus mykiss) gut microbiota is modulated by insect meal from Hermetia illucens prepupae in the diet. Reviews in Fish Biology and Fisheries 29: 465-486. https://doi. org/10.1007/s11160-019-09558-y

Tian, Z., Feng, Q., Sun, H., Liao, Y., Du, L., Yang, R., Li, X., Yang, Y. and $\mathrm{Xia}, \mathrm{Q}$., 2018. Isolation and purification of active antimicrobial peptides from Hermetia illucens L., and its effects on CNE2 cells. bioRxiv 353367. https://doi.org/10.1101/353367

Udayangani, R.M.C., Dananjaya, S.H.S., Nikapitiya, C., Heo, G.-J., Lee, J. and De Zoysa, M., 2017. Metagenomics analysis of gut microbiota and immune modulation in zebrafish (Danio rerio) fed chitosan silver nanocomposites. Fish \& Shellfish Immunololy 66: 173-184. https://doi.org/10.1016/j.fsi.2017.05.018

Urbanek, A., Szadziewski, R., Stepnowski, P., Boros-Majewska, J., Gabriel, I., Dawgul, M., Kamysz, W., Sonsowaska, D. and Gołębiowski, M., 2012. Composition and antimicrobial activity of fatty acids detected in the hygroscopic secretion collected from the secretory setae of larvae of the biting midge Forcipomyia nigra (Diptera: Ceratopogonidae). Journal of Insect Physiology, 58: 12651276. https://doi.org/10.1016/j.jinsphys.2012.06.014

Van Huis, A. 2017. Did early humans consume insects? Journal of Insects as Food and Feed 3: 161-163. https://doi.org/10.3920/ jiff2017.x006

Van Huis, A., 2020. Insects as food and feed, a new emerging agricultural sector: a review. Journal of Insects as Food and Feed 6: 27-44. https://doi.org/10.3920/jiff2019.0017

Vargas-Abúndez, A., Randazzo, B., Foddai, M., Sanchini, L., Truzzi, C., Giorgini, E., Gasco, L. and Olivotto, I., 2019. Insect meal based diets for clownfish: Biometric, histological, spectroscopic, biochemical and molecular implications. Aquaculture 498: 1-11. https://doi. org/10.1016/j.aquaculture.2018.08.018

Vogel, H., Muller, A., Heckel, D.G., Gutzeit, H. and Vilcinskas, A., 2018. Nutritional immunology: Diversification and diet-dependent expression of antimicrobial peptides in the black soldier fly Hermetia illucens. Developmental \& Comparative Immunology 78: 141-148. https://doi.org/10.1016/j.dci.2017.09.008
Wang, G., Peng, K., Hu, J., Yi, C., Chen, X., Wu, H. and Huang, Y., 2019. Evaluation of defatted black soldier fly (Hermetia illucens L.) larvae meal as an alternative protein ingredient for juvenile Japanese seabass (Lateolabrax japonicus) diets. Aquaculture 507: 144-154. https://doi.org/10.1016/j.aquaculture.2019.04.023

Wen, L.-F. and He, J.-G., 2012. Dose-response effects of an antimicrobial peptide, a cecropin hybrid, on growth performance, nutrient utilisation, bacterial counts in the digesta and intestinal morphology in broilers. British Journal of Nutrition 108: 1756-1763. https://doi.org/10.1017/S0007114511007240

World Health Organization (WHO), 2015. World Malaria Report 2015. WHO, Geneva, Switzerland, 280 pp. Available at https://www.who. int/malaria/publications/world-malaria-report-2015/report/en/.

Wu, Q., Patočka, J. and Kuča, K., 2018. Insect antimicrobial peptides, a mini review. Toxins 10: 461. https://doi.org/10.3390/toxins10110461

Xiang, J., Qin, L., Zhao, D., Xiong, F., Wang, G., Zou, H., Li, W., Li, M., Song, K. and Wu, S., 2019. Growth performance, immunity and intestinal microbiota of swamp eel (Monopterus albus) fed a diet supplemented with house fly larvae (Musca domestica). Aquaculture Nutrition 26: 693-704. https://doi.org/10.1111/anu.13029

Xiao, X., Jin, P., Zheng, L., Cai, M., Yu, Z., Yu, J. and Zhang, J., 2018. Effects of black soldier fly (Hermetia illucens) larvae mealprotein as a fishmeal replacement on the growth and immune index of yellow catfish (Pelteobagrus fulvidraco). Aquaculture Research 49: 1569-1577. https://doi.org/10.1111/are.13611

Yu, M., Li, Z., Chen, W., Rong, T., Wang, G. and Ma, X. 2019. Hermetia illucens larvae as a potential dietary protein source altered the microbiota and modulated mucosal immune status in the colon of finishing pigs. Journal of Animal Science and Biotechnology 10: 50. https://doi.org/10.1186/s40104-019-0358-1

Yu, M., Li, Z., Chen, W., Rong, T., Wang, G., Wang, F. and Ma, X. 2020b. Evaluation of full-fat Hermetia illucens larvae meal as a fishmeal replacement for weanling piglets: Effects on the growth performance, apparent nutrient digestibility, blood parameters and gut morphology. Animal Feed Science and Technology 264: 114431. https://doi.org/10.1016/j.anifeedsci.2020.114431

Yu, M., Li, Z., Chen, W., Wang, G., Rong, T., Liu, Z., Wang, F. and Ma, X. 2020a. Hermetia illucens larvae as a fishmeal replacement alters intestinal specific bacterial populations and immune homeostasis in weanling piglets. Journal of Animal Science 98: akz395. https:// doi.org/10.1093/jas/skz395

Zarantoniello, M., Bruni, L., Randazzo, B., Vargas, A., Gioacchini, G., Truzzi, C., Annibaldi, A., Riolo, P., Parisi, G., Cardinaletti, F., Tulli, F. and Olivotto, I., 2018. Partial dietary inclusion of Hermetia illucens (black soldier fly) full-fat prepupae in zebrafish feed: biometric, histological, biochemical, and molecular implications. Zebrafish 15: 519-532. https://doi.org/10.1089/zeb.2018.1596

Zhang, L-J. and Gallo, R.L., 2016. Antimicrobial peptides. Current Biology 26: R14-9. https://doi.org/10.1016/j.cub.2015.11.017

Zhou, Z., Karlsen, O., He, S., Olsen, R.E., Yao, B. and Ringo, E., 2013. The effect of dietary chitin on the autochthonous gut bacteria of Atlantic cod (Gadus morhua L.). Aquaculture Research 44: 18891900. https://doi.org/10.1111/j.1365-2109.2012.03194.x 
